This item was submitted to Loughborough's Research Repository by the author.

Items in Figshare are protected by copyright, with all rights reserved, unless otherwise indicated.

\title{
Examination of the optimal operation of building scale combined heat and power systems under disparate climate and GHG emissions rates
}

PLEASE CITE THE PUBLISHED VERSION

https://doi.org/10.1016/j.apenergy.2016.09.108

\section{PUBLISHER}

(C) Elsevier

\section{VERSION}

AM (Accepted Manuscript)

\section{PUBLISHER STATEMENT}

This work is made available according to the conditions of the Creative Commons Attribution-NonCommercialNoDerivatives 4.0 International (CC BY-NC-ND 4.0) licence. Full details of this licence are available at: https://creativecommons.org/licenses/by-nc-nd/4.0/

\section{LICENCE}

CC BY-NC-ND 4.0

\section{REPOSITORY RECORD}

Howard, Bianca, and V. Modi. 2016. "Examination of the Optimal Operation of Building Scale Combined Heat and Power Systems Under Disparate Climate and GHG Emissions Rates". Loughborough University. https://hdl.handle.net/2134/27337. 


\title{
Unraveling the optimal operation of combined heat and power systems under disparate climate and GHG emissions rates
}

\author{
B. Howard ${ }^{\mathrm{a}}, \mathrm{V} \cdot$ Modi $^{\mathrm{a}}$ \\ ${ }^{a}$ Department of Mechanical Engineering \\ Columbia University \\ 500 W 120th St, New York, NY 10027
}

\begin{abstract}
This work aims to elucidate notions concerning the ideal operation and greenhouse gas (GHG) emissions benefits of combined heat and power (CHP) systems by investigating how various metrics change as a function of the GHG emissions from the underlying electricity source, building use type and climate. Additionally, a new term entitled "CHP Attributable" reductions is introduced to quantify the benefits from the simultaneous use of thermal and electric energy, removing benefits achieved solely from fuel switching and generating electricity more efficiently.

The GHG emission benefits from implementing internal combustion engine, microturbines, and phosphoric acid (PA) fuel cell based CHP systems were evaluated through an optimization approach considering energy demands of prototypical hospital, office, and residential buildings in varied climates. To explore the effect of electric GHG emissions rates, the ideal CHP systems were determined under three scenarios: "High" GHG emissions rates, "Low" GHG emissions rates, and "Current" GHG emissions rate for a specific location.

The analysis finds that PA fuel cells achieve the highest GHG emission reductions in most cases considered, though there are exceptions. Common heuristics, such as electric load following and thermal load following, are the optimal operating strategy under specific conditions. The optimal CHP capacity and operating hours both vary as a function of building type, climate and GHG emissions rates from grid electricity. GHG emissions reductions can be as high as $49 \%$ considering a PA fuel cell for a prototypical hospital in Boulder, Colorado however, the "CHP attributable reductions are less than $10 \%$.
\end{abstract}

Keywords: Building Scale Combined Heat and Power, Greenhouse Gas Emissions, Controlled Random Search, Mixed Integer Linear Programming

\section{Nomenclature}

$\overline{\eta_{e l}}$ CHP nominal electrical efficiency

$\eta$ CHP efficiency

$X$ CHP electrical capacity

\footnotetext{
* Corresponding author

Email address: bnh2111@columbia.edu (B. Howard)
} 
$f_{t}$ CHP system fuel consumption in time step $t$

$d_{l}$ efficiency degradation at load $l$

$d_{f}$ efficiency degradation at load $f$

$p_{t}^{h}, p_{t}^{l}$ piecewise linear power output of the CHP system in time step $t$

$q_{t}$ CHP system thermal output in time step $t$

be break-even GHG emissions rate for grid electricity

$e_{b}$ GHG emissions coefficient for thermal energy produced from an on-site boiler $\left(\mathrm{g} \mathrm{CO}_{2} \mathrm{e} / \mathrm{kWh}\right)$

$e_{n g}$ GHG emissions coefficient for natural gas $\left(\mathrm{g} \mathrm{CO}_{2} \mathrm{e} / \mathrm{kWh}\right)$

$\eta_{e l}$ CHP electrical efficiency

$e_{g}$ GHG emissions coefficient of electricity from the grid $\left(\mathrm{g} \mathrm{CO}_{2} \mathrm{e} / \mathrm{kWh}\right)$

$e_{b}$ GHG emissions coefficient for thermal energy produced from an on-site boiler $\left(\mathrm{g} \mathrm{CO}_{2} \mathrm{e} / \mathrm{kWh}\right)$

$E_{t}$ electricity demand of the building in time step $t$

$H_{t}$ thermal demand of the building in time step $t$

$e_{t}$ electrical energy produced by the CHP system and used by the building in hour $t$

$h_{t}$ thermal energy produced by the CHP system and used by the building in hour $t$

$w_{t}$ binary variable defining piecewise linear CHP power output

$\mu_{t}$ operating status of the CHP system in hour $t$

$\Delta$ search range in $\mathrm{kW}$ for controlled random search algorithm

$\phi$ probability of accepting a solution with poor objective function for controlled random search

\section{Introduction}

Combined heat and power (CHP) systems are a type of distributed generation technology where electricity and thermal energy are produced and consumed. CHP systems are based on electricity generation systems,, such as internal combustion engines, gas turbines and fuel cells. In a CHP arrangement these systems are equipped with heat recovery systems to allow the waste heat to supply a nearby thermal demand.

Distributed generation systems, including those with CHP systems, have been deemed advantageous for a variety of reasons. Major benefits potentially include the deferment of large investments in the electric transmission and distribution infrastructure, increased in grid reliability and power quality if ideally located, and more efficient use of resources with the use of CHP configurations $[1,2,3,4]$. As more efficient use of resources results in greenhouse gas (GHG) emissions reductions, CHP systems have been promoted by many policymakers in the United States and Europe $[5,6,7,8]$. 
However, the geographic scales of use for CHP systems have become increasingly smaller. Original uses were in industrial or district energy systems that utilized waste heat to serve large thermal demand centers. More recently CHP systems have been implemented at the building level to meet local electricity, space heating and water heating demands $[9,10]$. However with diminished size comes additional challenges.

At the building scale, the electric and thermal demands are more variable over the year, as one can not leverage the smoothing that occurs with the aggregation of building demands. Moreover, performance parameters diminish with size, potentially impacting the GHG emissions benefits for buildings with lower energy demands [11]. In consequence determining the proper prime mover, capacity, and operational strategy, i.e. the output of the CHP system in each time step, becomes increasing important and complex.

This has led to a large body of research analyzing the how to best operate CHP system under various sets of conditions [12, 13, 14, 15, 16, 5, 17, 18, 19, 20, 21, 22, 23, 24, 25, 26, 27, 28]. "Best" has been defined in many ways including minimal cost, energy consumption, GHG emissions and exergy efficiency. The disparate conditions include climatic conditions, energy cost structures, CHP system characterizations, and GHG emissions from the baseline system. In this work we focus on CHP systems operated to minimize GHG emissions, thus we review a select set of papers that have evaluated the impacts on this criteria. Table 1 describes the scenarios explored in several studies on CHP systems, specifically highlighting the building use cases, climate zone, CHP system type (prime mover), GHG emissions from baseline scenarios, operating strategy, sizing strategy and resulting conclusions.

A range of building use cases, or building types, have been considered from industrial, commercial, and residential. However studies considering the largest diversity of building types typically considered the effects in a single climate under fixed GHG emissions rates from grid electricity and thermal demands [17, 25]. Conversely Mago et al. [15] evaluated the performance of CHP systems in various climates but only considered a single use case. Additionally both research teams used a simplified operating and sizing strategies that do not result in the largest GHG emissions reductions. Operating strategies vary from heuristics such as continuous output, electrical load following, thermal load following, and maximum output. For the heuristics, the operating strategy is determined without consideration of the demand. Optimal strategies attempt to determine the best way to operate a system considering the building demands and constraints on the CHP systems themselves. Each of these strategies from heuristics to optimal linear, mixed-integer linear and nonlinear programs has been used to estimate GHG emissions savings from CHP systems. Moreover, researchers have compared the optimal approaches to the heuristics, resulting in mixed findings. Ghadimi et al. [24] found that the optimal approach was well approximated by the electric load following heuristic. Yet Hueffed and Mago [17] have found that neither the electric load following or a thermal load following approach could match the reductions in the optimal case. Lastly very few researchers in the studies reviewed search for the optimal size of the CHP system. More commonly the system capacity is determined a priori.

In the studies reviewed, the GHG emissions reductions from implementing CHP systems ranged from $0-52 \%$. With the many and varied evaluations, it is difficult to discern how different factors such as building type, climate, prime mover, and grid GHG emissions rates affect the GHG emissions benefits of CHP systems.

Another aspect not addressed in other studies is quantifying the added benefit of the combined heat and power operation. For example Hueffed and Mago [29] consider arguably high values of GHG emissions from grid electricity and find reductions up to $52 \%$. Given this high GHG emissions 
rate from grid electricity, it is unclear how much benefit comes from operating in combined heat and power mode versus switching to a low carbon fuel and generating electricity at a higher efficiency. 
Table 1: Description of selected studies on the operation of CHP Systems.

\begin{tabular}{|c|c|c|c|c|c|c|c|}
\hline Study & $\begin{array}{l}\text { Use } \\
\text { Case }\end{array}$ & $\begin{array}{l}\text { Climate } \\
\text { Zone }\end{array}$ & $\begin{array}{l}\text { CHP } \\
\text { System }\end{array}$ & $\begin{array}{l}\text { GHG emis- } \\
\text { sions rate }\end{array}$ & $\begin{array}{l}\text { Operating } \\
\text { Strategy }\end{array}$ & $\begin{array}{l}\text { Sizing } \\
\text { Strategy }\end{array}$ & Conclusions \\
\hline $\begin{array}{l}\text { Ren } \\
\text { and } \\
\text { Gao } \\
{[21]}\end{array}$ & $\begin{array}{l}\text { Resid- } \\
\text { ential }\end{array}$ & $\begin{array}{l}\text { Mixed- } \\
\text { Humid }\end{array}$ & $\begin{array}{l}\text { ICE, } \\
\text { Fuel } \\
\text { Cells }\end{array}$ & $\begin{array}{lc}\mathrm{E}: & 370 \\
\mathrm{gCO}_{2} / \mathrm{kWh} \\
\mathrm{T}: & 229 \\
\mathrm{gCO}_{2} / \mathrm{kWh}\end{array}$ & $\begin{array}{l}\text { Emission } \\
\text { optimal mixed- } \\
\text { integer linear } \\
\text { program }\end{array}$ & $\begin{array}{l}\text { fixed } 1 \mathrm{~kW} \\
\text { systems }\end{array}$ & $\begin{array}{l}1-9 \mathrm{CO}_{2} \text { emis- } \\
\text { sion reductions }\end{array}$ \\
\hline $\begin{array}{l}\text { Ghadimi } \\
\text { et al. } \\
{[24]}\end{array}$ & $\begin{array}{l}\text { Indus- } \\
\text { trial } \\
\text { plant }\end{array}$ & $\begin{array}{l}\text { Not } \\
\text { Speci- } \\
\text { fied }\end{array}$ & $\mathrm{ICE}$ & $\begin{array}{lr}\mathrm{E}: & 978 \\
\mathrm{gCO}_{2} \mathrm{e} / \mathrm{kWh} & \\
\mathrm{T}: & 247-617 \\
\mathrm{gCO}_{2} \mathrm{e} / \mathrm{kWh}\end{array}$ & $\begin{array}{l}\text { Continuous, } \\
\text { Electric Load } \\
\text { Following, } \\
\text { Thermal Load } \\
\text { Following, } \\
\text { GHG optimal } \\
\text { non-linear } \\
\text { optimization }\end{array}$ & $\begin{array}{lr}\text { Search } \\
\text { space at } \\
100 \quad \mathrm{~kW} \\
\text { increments }\end{array}$ & 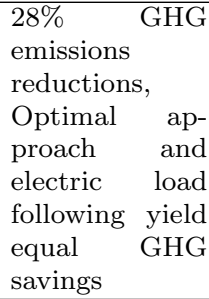 \\
\hline $\begin{array}{l}\text { Mago } \\
\text { et al. } \\
{[15]}\end{array}$ & $\begin{array}{l}\text { Hosp- } \\
\text { ital }\end{array}$ & $\begin{array}{l}\text { All cli- } \\
\text { mate } \\
\text { zones }\end{array}$ & $\begin{array}{l}\text { Generic } \\
\text { prime } \\
\text { mover }\end{array}$ & $\begin{array}{l}\mathrm{E}: 328-854 \\
\mathrm{gCO}_{2} / \mathrm{kWh} ; \\
\mathrm{T}: \text { Not speci- } \\
\text { fied }\end{array}$ & Continuous & $\begin{array}{l}\text { Various } \\
\text { sizes re- } \\
\text { lated to } \\
\text { electric- } \\
\text { ity and } \\
\text { thermal } \\
\text { demands } \\
\text { of the } \\
\text { building }\end{array}$ & $\begin{array}{l}0-17.2 \% \quad \mathrm{CO}_{2} \\
\text { emission reduc- } \\
\text { tions }\end{array}$ \\
\hline $\begin{array}{l}\text { Mago } \\
\text { and } \\
\text { Smith } \\
{[17]}\end{array}$ & Various & Cold & $\begin{array}{l}\text { Generic } \\
\text { prime } \\
\text { mover }\end{array}$ & $\begin{array}{lr}\mathrm{E}: & 533 \\
\mathrm{gCO}_{2} \mathrm{e} / \mathrm{kWh} ; \\
\mathrm{T}: & 200 \\
\mathrm{gCO}_{2} \mathrm{e} / \mathrm{kWh}\end{array}$ & Continuous & $\begin{array}{l}\text { Capacity } \\
\text { equal to } \\
30 \% \text { aver- } \\
\text { age hourly } \\
\text { demand }\end{array}$ & $\begin{array}{l}16-21 \% \text { GHG } \\
\text { emissions } \\
\text { reductions }\end{array}$ \\
\hline $\begin{array}{l}\text { Howard } \\
\text { et al. } \\
{[25]}\end{array}$ & Various & $\begin{array}{l}\text { Mixed- } \\
\text { Humid }\end{array}$ & $\begin{array}{l}\text { ICE, } \\
\text { micro- } \\
\text { turbines }\end{array}$ & $\begin{array}{lr}\mathrm{E}: & 561 \\
\mathrm{gCO}_{2} \mathrm{e} / \mathrm{kWh} ; \\
\mathrm{T}: & 239 \\
\mathrm{gCO}_{2} \mathrm{e} / \mathrm{kWh}\end{array}$ & $\begin{array}{l}\text { Electric Load } \\
\text { Following }\end{array}$ & $\begin{array}{l}30-3000 \\
\mathrm{~kW} \text {, Search } \\
\text { space at } 1 \\
\mathrm{~kW} \text { incre- } \\
\text { ments }\end{array}$ & $\begin{array}{l}\text { Average GHG } \\
\text { emissions } \\
\text { reductions } 16 \%\end{array}$ \\
\hline $\begin{array}{l}\text { Hawkes } \\
\text { and } \\
\text { Leach } \\
{[13]}\end{array}$ & $\begin{array}{l}\text { Resid- } \\
\text { ential }\end{array}$ & Marine & $\begin{array}{l}\text { ICE, } \\
\text { Fuel } \\
\text { Cell, } \\
\text { Stirling } \\
\text { Engine }\end{array}$ & $\begin{array}{lc}\mathrm{E}: & 430 \\
\mathrm{gCO}_{2} / \mathrm{kWh} ; \\
\mathrm{T}: & 189 \\
\mathrm{gCO}_{2} / \mathrm{kWh}\end{array}$ & $\begin{array}{l}\text { Electric Load } \\
\text { Following, } \\
\text { Thermal Load } \\
\text { Following, } \\
\text { Cost-Optimal } \\
\text { Quadratic } \\
\text { Programming }\end{array}$ & $\begin{array}{l}\text { fixed } 2 \mathrm{~kW} \\
\text { systems }\end{array}$ & $\begin{array}{l}21 \% \text { reduction } \\
\text { with optimal } \\
\text { dispatch, heat- } \\
\text { led strategy } \\
\text { can be better } \\
\text { for GHG emis- } \\
\text { sions than cost } \\
\text { optimal }\end{array}$ \\
\hline $\begin{array}{l}\text { Hueffed } \\
\text { and } \\
\text { Mago } \\
{[29]}\end{array}$ & $\begin{array}{l}\text { Small } \\
\text { Office }\end{array}$ & $\begin{array}{l}\text { Cold- } \\
\text { Very } \\
\text { Cold }\end{array}$ & $\begin{array}{l}\mathrm{ICE} \\
(\mathrm{CCHP})\end{array}$ & $\begin{array}{lr}\mathrm{E}: & 789-1230 \\
\mathrm{gCO}_{2} / \mathrm{kWh} ; \\
\mathrm{T}: \quad 188 \\
\mathrm{gCO}_{2} / \mathrm{kWh}\end{array}$ & $\begin{array}{l}\text { Constant } \\
\text { Dispatch, Elec- } \\
\text { trical Load } \\
\text { Following, } \\
\text { Thermal Load } \\
\text { Following, } \\
\text { GHG Opti- } \\
\text { mal Linear } \\
\text { Program }\end{array}$ & 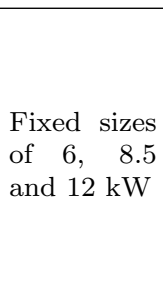 & $\begin{array}{lr}9-52 \% & \mathrm{CO}_{2} \\
\text { emission } & \text { re- } \\
\text { ductions, } & \mathrm{GHG} \\
\text { optimal pro- } \\
\text { vides larger } \\
\text { reductions } \\
\text { than all other } \\
\text { heuristics }\end{array}$ \\
\hline $\begin{array}{l}\text { Wang } \\
\text { et al. } \\
{[30]}\end{array}$ & Hotel & $\begin{array}{l}\text { Hot- } \\
\text { Humid }\end{array}$ & $\begin{array}{l}\text { Micro- } \\
\text { turbine } \\
(\mathrm{CCHP})\end{array}$ & $\begin{array}{ll}\mathrm{E}: & 877-968 \\
\mathrm{gCO}_{2} / \mathrm{kWh} \\
\mathrm{T}: & 185-255 \\
\mathrm{gCO}_{2} / \mathrm{kWh}\end{array}$ & $\begin{array}{l}\text { Electric Load } \\
\text { Following, } \\
\text { Thermal Load } \\
\text { Following }\end{array}$ & fixed size & $\begin{array}{l}9-25 \quad \% \mathrm{CO}_{2} \\
\text { emission reduc- } \\
\text { tions }\end{array}$ \\
\hline
\end{tabular}

a Climate Zones Estimated to equivalent US Department of Energy Building America climates zones [31]

ICE: Internal Combustion Engine, CCHP: Combined Cooling Heating and Power, E: GHG (or CO 2 ) emissions rate from the electricity source, $\mathrm{T}$ : $\mathrm{GHG}\left(\right.$ or $\mathrm{CO}_{2}$ ) emgissions rate from the thermal energy source 
The aim of this analysis is to clarify and unify statements made in previous works about CHP systems by determining how the optimal operating strategy, operating hours, system capacity, and ideal CHP system type change as a function of the GHG emissions from the underlying electricity source considering a broad range of building types and climates. We seek to provide analysis that can be generalized to allow for an easier understanding of how CHP systems should be sized and operated to reduce GHG emissions. In addition, this work defines a new term, CHP attributable reductions, that quantifies the amount of savings that are specifically due to the simultaneous use of thermal and electrical energy produced by a CHP system.

The analysis is performed by finding, through an optimal sizing and dispatch program, the CHP system that maximizes GHG emissions reductions for prototypical hospitals, office and residential buildings, of different sizes, in 16 climates, under "high" and "low" GHG emissions scenarios. The results of the optimization are explored to draw general conclusions about the reduction potential, ideal prime mover, CHP system capacities and operational strategies under the various scenarios. "CHP attributable" GHG emissions reductions are defined by considering the difference between two optimizations: one where the objective function includes considerations for both thermal and electric demands and one where only savings from electricity production are considered.

The remainder of this paper is organized as follows: Section 2 describes the governing systems including the building energy demands as a function of building type and climate, greenhouse gas emissions rates from electric and thermal energy production, and CHP technologies and performance parameters. Section 3 describes the break-even point for GHG emissions reductions from CHP systems. Section 4 describes the mixed integer linear program and controlled random search algorithm utilized to determine the optimal capacity and operational strategy. Section 5 describes and discusses the results of the analysis and Section 6 provides the final remarks and conclusions.

\section{Defining the Governing Systems}

For the analysis, a single building is considered with thermal and electric energy demands that can be satisfied by a local CHP system, on-site boiler, or electricity provided through the regional power grid. The following sections define the building energy demands, the GHG emissions produced from thermal and electricity energy sources, and the CHP system performance characteristics.

\subsection{Building Electric and Thermal Energy Demands}

The building energy demands used in this analysis were those simulated for the DOE commercial building benchmark buildings [32]. The goals of the simulations, performed in EnergyPlus, are to provide an estimate of the energy demands of different building types in various climates behave on average. More specifically the electricity, space heating, and water heating demands for the hospital, large office (office) and mid-rise residential (residential) building types for 16 cities representing various climate regions were simulated. The climate regions across the United States are defined by the building performance association into 8 different regions: Hot-Dry, Hot-Humid, Mixed-Humid, Mixed-Dry, Marine, Cold, Very Cold, and Subarctic. Full descriptions of the climate regions can be found in [31]. Using these simulations allows for exploration of the effects of both building usage and climate.

One of the aims of this analysis is to determine GHG emissions reductions as a function of building size. Building size in this analysis, is proxy for the magnitude of the building energy demands. Therefore to maintain a common point of reference, the total annual building energy demands were scaled to two different values: $10^{7} \mathrm{kWh}$ per year and $10^{6} \mathrm{kWh}$ per year representing 
Table 2: Percent annual electricity, space heating, and water heating demand by city and climate zone for Hospital, Office and Residential Buildings

\begin{tabular}{|l|l|l|l|l|l|l|l|l|l|l|l|}
\cline { 3 - 11 } \multicolumn{2}{c|}{} & \multicolumn{3}{c|}{} & \multicolumn{3}{c|}{ \% Annual Non Cooking Energy Demand } \\
\cline { 3 - 12 } \multicolumn{2}{c|}{} & \multicolumn{3}{c|}{ Office } & \multicolumn{3}{c|}{$\begin{array}{c}\text { Multi-Family } \\
\text { Residential }\end{array}$} & \multicolumn{3}{c|}{ Hospital } \\
\hline Climate Zone & City & E & SPH & WH & E & SPH & WH & E & SPH & WH \\
\hline Subarctic & Fairbanks, AL & 46.2 & 53.1 & 0.7 & 17.6 & 74.9 & 7.5 & 58.2 & 40.1 & 1.7 \\
\hline Very Cold & Duluth, MN & 61.3 & 37.9 & 0.8 & 23.1 & 67.6 & 9.3 & 68.7 & 29.7 & 1.6 \\
\hline Cold & Minneapolis, MN & 68.4 & 30.9 & 0.7 & 27.8 & 62.6 & 9.6 & 71.3 & 27.3 & 1.4 \\
\hline Cold & Mt. Helena, MT & 72.9 & 26.3 & 0.8 & 29.5 & 59.6 & 10.9 & 73.7 & 24.7 & 1.6 \\
\hline Cold & Chicago, IL & 75.5 & 23.8 & 0.7 & 31.8 & 58.0 & 10.2 & 73.7 & 25.0 & 1.3 \\
\hline Cold & Boulder, CO & 82.0 & 17.2 & 0.8 & 36.1 & 52.0 & 12.0 & 77.7 & 20.8 & 1.5 \\
\hline Marine & Seattle, WA & 74.7 & 24.5 & 0.7 & 34.1 & 54.2 & 11.7 & 71.6 & 27.1 & 1.3 \\
\hline Marine & San Francisco, CA & 87.4 & 11.8 & 0.8 & 44.9 & 40.3 & 14.8 & 74.0 & 24.7 & 1.3 \\
\hline Mixed-Dry & Albuquerque, NM & 84.8 & 14.5 & 0.7 & 45.0 & 42.8 & 12.2 & 78.0 & 20.7 & 1.3 \\
\hline Mixed-Humid & Baltimore, MD & 79.4 & 20.0 & 0.6 & 37.9 & 51.7 & 10.5 & 74.3 & 24.6 & 1.1 \\
\hline Mixed-Humid & Atlanta, GA & 87.2 & 12.2 & 0.5 & 49.8 & 38.7 & 11.5 & 76.5 & 22.5 & 1.0 \\
\hline Hot-Dry & Phoenix, AZ & 84.5 & 5.1 & 0.4 & 74.4 & 15.9 & 9.7 & 78.5 & 20.7 & 0.8 \\
\hline Hot-Dry & Las Vegas, NV & 91.7 & 7.8 & 0.5 & 62.7 & 26.6 & 10.7 & 77.9 & 21.1 & 1.0 \\
\hline Hot-Dry & Los Angeles, CA & 94.4 & 5.0 & 0.6 & 64.1 & 18.7 & 17.1 & 77.2 & 21.7 & 1.1 \\
\hline Hot-Humid & Houston, TX & 93.1 & 6.5 & 0.5 & 66.6 & 22.4 & 11.0 & 78.8 & 20.3 & 0.9 \\
\hline Hot-Humid & Miami, FL & 98.5 & 1.1 & 0.4 & 88.3 & 1.7 & 10.1 & 81.3 & 17.9 & 0.8 \\
\hline
\end{tabular}

E: Electricity Demand, SPH: Space Heating Demand, WH: Water Heating Demand

"Large" and "Small" buildings respectively. In each scenarios, the annual energy demand of each building across all building types is the same however the relative magnitude of the thermal (space and water) and electricity demands are different. This allows for a direct comparison alleviating the influence of the relative energy demands as a function of size for each building. The simulated annual non-cooking energy consumption by electric, space heating, and water heating demands for each location are shown in Table 2 .

It should be noted that by adjusting the annual energy demands, the physical size of the buildings are changing as well if one considers the building's energy intensity to be constant. The large buildings could be between 450,000 to $1,200,000$ sq. ft. for residential buildings, 500,000 to 850,00 sq. ft. for office buildings, and 185,000 to 250,000 sq. ft.

\subsection{GHG Emissions from Electricity and Thermal Production}

In the United States, electricity is typically provided through the electric grid from a slew of power plants each having their own GHG emissions characteristics. The simplest approximation, and the one utilized in this work, is to define the GHG emissions produced by a set of power plants by an average GHG emission rate, or the grams of GHG emissions (in carbon dioxide equivalent) produced per $\mathrm{kWh}$ of electricity produced annually.

Average GHG emission rates have been estimated for different regions across the United States by the EPA in their emissions and generation integrated database (eGRID). They make estimates for varying geographic scales from the state to the whole of the US. The eGRID estimates do not account for transmission across the geographic boundaries, only the emissions from power plants physically located in that region. This can lead to skewed estimates if a particular state relies on 
Table 3: 16 simulated building locations and the corresponding NERC subregion GHG emissions rates

\begin{tabular}{c|c} 
City & $\begin{array}{c}\text { NERC Subregion } \\
\text { GHG emissions rate } \\
\left(\mathrm{g} \mathrm{CO} \mathrm{CO}_{2} \mathrm{e} / \mathrm{kWh}\right)\end{array}$ \\
\hline Fairbanks, AL & 582 \\
\hline Duluth, MN & 725 \\
\hline Minneapolis, MN & 725 \\
\hline Mt. Helena, MT & 725 \\
\hline Chicago, IL & 693 \\
\hline Boulder, CO & 831 \\
\hline Seattle, WA & 169 \\
\hline San Francisco, CA & 300 \\
\hline Albuquerque, NM & 542 \\
\hline Baltimore, MD & 432 \\
\hline Atlanta, GA & 432 \\
\hline Phoneix, AZ & 542 \\
\hline Las Vegas, NV & 542 \\
\hline Los Angeles, CA & 300 \\
\hline Houston, TX & 537 \\
\hline Miami, FL & 535
\end{tabular}

the generation of a neighboring region. To mitigate that effect, the GHG emissions rates for the buildings in each of the 16 cities were defined by their corresponding eGRID primary subregions. The cities and their corresponding electric GHG emissions rate is shown in Table 3.

However in this work we also seek to determine how the GHG emissions from electricity production effect how one would size and operate a CHP system. Therefore we also define two generic GHG emissions scenarios for which we will evaluate the results of each system. The first scenario is termed the "High" GHG emissions scenario. In this scenario the GHG emissions rate from grid electricity is set to $750 \mathrm{~g} \mathrm{CO}_{2} \mathrm{e} / \mathrm{kWh}$. To provide a specific example, this rate represents an electricity system where $60 \%$ is provided by a typical coal power plant and $40 \%$ is provided by a natural gas power plant, considering average US power plant efficiency by fuel source. The second scenario is termed the "Low" GHG emissions scenario, where the GHG emissions rate from grid electricity is defined as $300 \mathrm{~g} \mathrm{CO}_{2} \mathrm{e} / \mathrm{kWh}$. This scenario represents an electricity system where $70 \%$ is provided by natural gas power plants and $30 \%$ from renewable sources. Considering the values in Table 3 , these two scenarios do indeed represent "High" and "Low" GHG emission rates.

For thermal energy production, many commercial and residential buildings in the United States use natural gas boilers or furnaces [33]. Boilers are very efficient at converting natural gas in to thermal energy with factory efficiencies up to $90 \%$. With wear and tear however the efficiencies diminish over time. In this work, the boiler thermal efficiency was assumed to be $80 \%$ leading to a GHG emission rate of $225 \mathrm{~g} \mathrm{CO}_{2} \mathrm{e} / \mathrm{kWh}$. This assumption holds true for all scenarios considered in this work.

\subsection{CHP Technology Characterization}

This section provides a brief overview of CHP systems, the parameters use to characterize them, and how the performance was mathematically defined for the subsequent optimization.

The CHP systems evaluated are those applicable at the building scale. The main considerations were system size and load following capability. In a load following operating scheme, the CHP 
Figure 1: Electrical Efficiency as a function of Electrical Capacity from various manufacturing specifications for thermal systems. Maximum efficiency as defined by a piecewise linear function is shown in red.

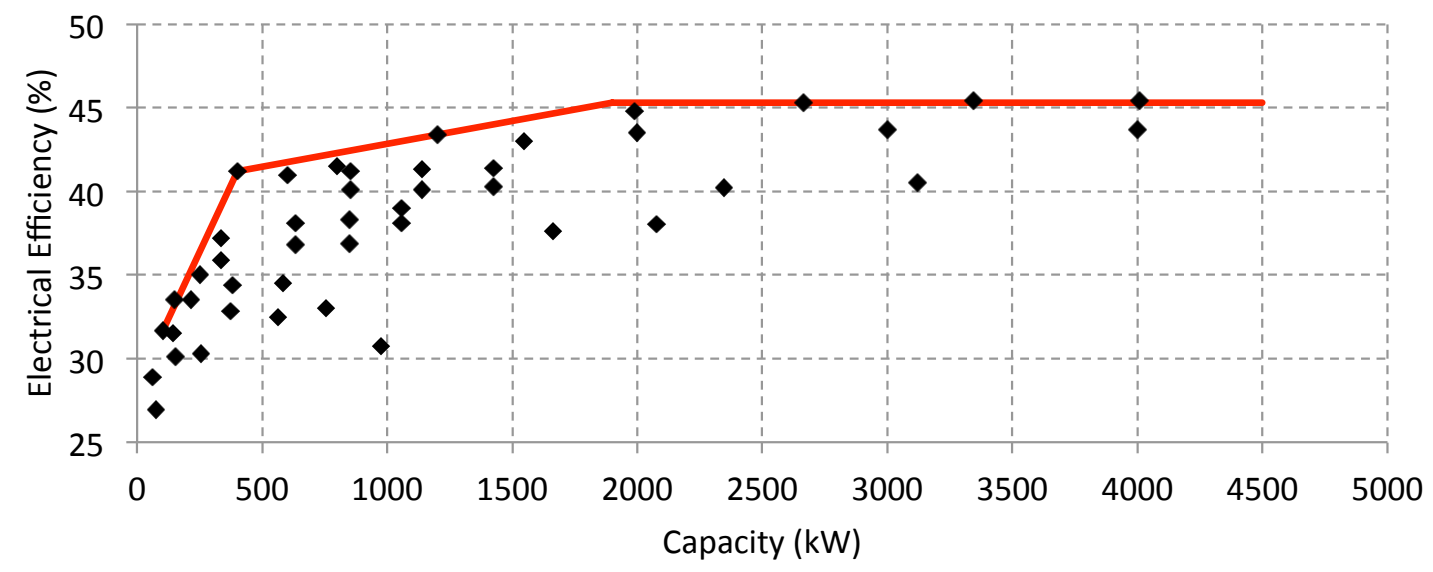

system is expected to modulate its output to meet demands. These constraints led to the consideration of three different types of CHP systems: microturbines, internal combustion engines, and phosphoric acid (PA) fuel cells all fueled by natural gas.

The main characteristics to describe the operation of a CHP system are the nominal electrical efficiency $\left(\eta_{e l}\right)$, CHP efficiency $(\eta)$, electrical capacity $(X)$, and part load efficiency. The nominal electrical efficiency is the ratio of electricity produced to the energy content of the fuel source at maximum capacity. The CHP efficiency is the ratio of the aggregate useful thermal and electrical energy to the energy content of the fuel source. The electrical capacity is the maximum electrical power output of the CHP system. Lastly the part-load efficiency, defined by more than one parameter, describes the degradation of the efficiency when not operating at the full electrical capacity.

The thermal systems and the electrochemical systems differ in the relationship between these parameters.

\subsubsection{Nominal Electrical Efficiency and System Capacity}

For internal combustion systems, the nominal electrical efficiency is a function of the electrical capacity (or the system size). More specifically the electrical efficiency decreases as the capacity decreases due to increased mechanical losses. To capture this dependence, the nominal electrical efficiencies for internal combustion engines of various sizes were collected from manufacturing specifications $[34,34,35,36]$. As illustrated in Figure 1, the nominal electrical efficiency increases rapidly until approximately $400 \mathrm{~kW}$, slowly increases between $400 \mathrm{~kW}$ and $2,000 \mathrm{~kW}$, and then plateaus to around a constant $45 \%$ electrical efficiency.

This dependency was modeled as a piecewise linear curve considering only the highest efficiencies at a given capacity which is also visualized in Figure 1. The mathematical relationship is described as follows 


$$
\overline{\eta_{e l}}(X)= \begin{cases}3.2 * 10^{-4} X+.287, & X \leq 401 \\ 2.6 * 10^{-5} X+.402, & 401<X \leq 1990 \\ 0.453, & X>1990\end{cases}
$$

where $\mathrm{X}$, the electric capacity, is in $\mathrm{kW}$ and $\overline{\eta_{e l}}$ is the nominal electrical efficiency. Characterizing the relationship between the nominal electrical efficiency and system capacity as a continuous function is done to allow for ease of computation.

The same procedure was followed for microturbine systems $[37,38]$ resulting in the following piecewise linear curve

$$
\overline{\eta_{e l}}(X)= \begin{cases}7.4 * 10^{-4} X+.238, & 30<X \leq 125 \\ 0.33, & X>125\end{cases}
$$

Fuel cell systems operate under different principles than thermal systems. The capacity of a fuel cell systems is created by stacking individual cells of low voltage in series. This decouples the electrical efficiency from the size. This can be seen in commercial products with PureCell [39] offering a $5 \mathrm{~kW}$ and $400 \mathrm{~kW}$ PA fuel cells with nominal electrical efficiencies of $40 \%$ and $42 \%$, respectively. This differs for thermal system where the electrical efficiency could change from $30 \%$ to over $40 \%$ over the same range (see Figure 1). Therefore fuel cell systems were modeled with constant nominal electrical efficiency of $40 \%$ over all sizes.

\subsubsection{Part-load Electrical Efficiency}

In addition to the electrical efficiency changing as a function of size, for all systems considered the electrical efficiency reduces when not operating at the maximum capacity. Figure 2 depicts typical efficiency reduction as a function of part load for fuel cells, internal combustion engines and microturbines reproduced from [11].

Each of the systems has slightly different part-load behavior. Fuel cells can maintain their nominal electrical efficiency until approximately $60 \%$ of the rated capacity after which the efficiency degrades rapidly. For microturbines and internal combustion engines the efficiencies slowly degrade with internal combustion engines having more severe degradation.

The fuel consumption as a function of load is called the heat rate. The part-load efficiencies were converted to heat rates and those heat rates were modeled as piece-wise linear curves defined by two segments that describe the operation in "low" and "high" output regimes. Given this definition the fuel consumption of the system is defined as follows

$$
f_{t}=A^{h} p_{t}^{h}+A^{l} p_{t}^{l}+B \mu_{t}
$$

where

$$
\begin{gathered}
A^{h}=\frac{1-\frac{1}{d_{f}}}{\overline{\eta_{e l}}(1-f)} \\
A^{l}=\frac{\frac{1}{d_{f}}-\frac{1}{\bar{d}_{l}}}{\bar{\eta}_{e l}}(f-l) \\
B=\frac{X}{\overline{\eta_{e l}}}\left[\frac{1}{d_{l}}-\frac{l}{f-l}\left(\frac{1}{d_{f}}-\frac{1}{d_{l}}\right)\right]
\end{gathered}
$$


Figure 2: Typical Part-load electrical efficiency degradation for fuel cells, internal combustion engines, and microturbines $[11]$

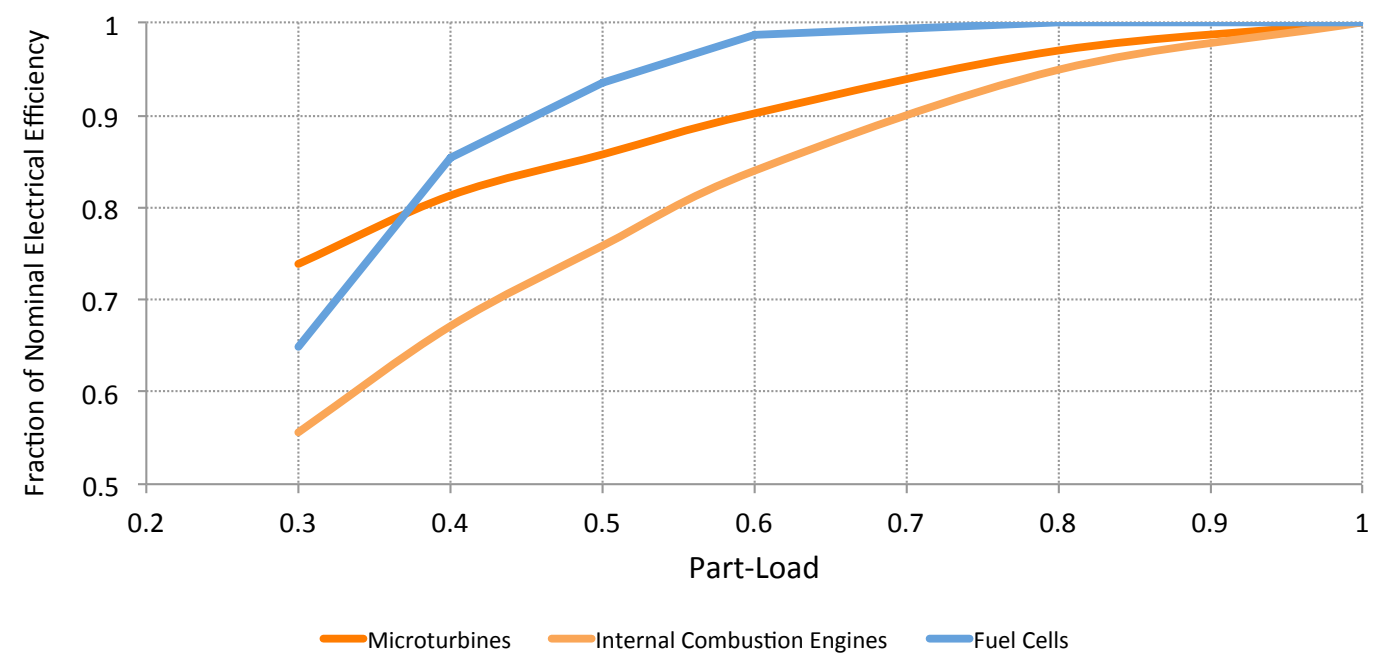

Table 4: CHP System Performance Parameters, [39, 37, 38, 36]

\begin{tabular}{c|c|c|c} 
Parameter & Microturbines & Internal Combustion Engines & PAFC \\
\hline$l$ & 0.3 & 0.3 & 0.3 \\
\hline$f$ & 0.8 & 0.8 & 0.6 \\
\hline$d_{l}$ & 0.75 & 0.55 & 0.75 \\
\hline$d_{f}$ & 0.97 & 0.95 & 1.0 \\
\hline$\eta$ & 0.90 & 0.85 & 0.9
\end{tabular}

. In the equations above $d_{l}$ and $d_{f}$ are the efficiency degradation at part-loads $l$, and $f$, respectively. Due to the piecewise linear formulation, the power output of the CHP system has been defined by two variables $p_{t}^{h}$ and $p_{t}^{l}$ that when summed equal the total output electrical energy output of the CHP system in timestep $t$.

By letting the CHP efficiency $\eta$ be constant over all loads, we can also define the thermal output of the CHP system as follows

$$
q_{t}=\eta\left(A^{h} p_{t}^{h}+A^{l} p_{t}^{l}+B \mu_{t}\right)-p_{t}^{h}-p_{t}^{l}
$$

For each system type considered the part-load performance parameters are shown in Table 4 .

\section{Break-even GHG emissions rates}

An avoided burden approach was used to estimate the GHG emissions reductions from implementing CHP systems. This approach estimates the GHG emissions that would have been produced from the current method of electricity and thermal energy generation and subtracts the estimated 
Table 5: Break-even Electric GHG emissions rates for thermal and fuel cell CHP systems

\begin{tabular}{c|c} 
System Type & Break-Even Emissions $\left(\mathrm{g} \mathrm{CO}_{2} \mathrm{e} / \mathrm{kWh}\right)$ \\
\hline Microturbines & $115-160$ \\
\hline Internal Combustion Engines & $161-202$ \\
\hline PA Fuel Cells & $153-171$
\end{tabular}

GHG emissions produced from the CHP operation. The difference is considered the GHG emissions savings.

With the fuel source and efficiency of the CHP system and the GHG emissions rate for thermal energy production defined, one can determine the GHG emission rate from electricity production for which a CHP system will have zero impact on GHG emissions. This value, or the break-even point, is calculated as follows

$$
b e=\frac{e_{n g}}{\eta_{e l}}-\frac{e_{b} *\left(\eta-\eta_{e l}\right)}{\eta_{e l}}
$$

where be is the break-even GHG emissions rate for grid electricity, $e_{b}$ is the GHG emissions coefficient for thermal energy produced from an on-site boiler $\left(\mathrm{g} \mathrm{CO}_{2} \mathrm{e} / \mathrm{kWh}\right), e_{n g}$ is the GHG emissions coefficient for natural gas $\left(\mathrm{g} \mathrm{CO}_{2} \mathrm{e} / \mathrm{kWh}\right), \eta$ is the total CHP efficiency, and $\eta_{e l}$ is the CHP electrical efficiency. As the electrical efficiencies vary as a function of capacity and load, the break-even GHG emission rates are defined for the range of efficiencies possible for each system type and are shown in Table 5. These values define the value of GHG emissions from grid electricity for which a CHP system would neither increase of decrease GHG emissions.

\section{Estimation Methodology}

Given the governing systems defined in section 2, the task is to now for each set of building energy demands determine the system capacity and operating strategy that minimizes the overall GHG emissions. Allowing the nominal electrical efficiency to be a function of the capacity while also defining the part-load efficiency, however, leads to a complex problem formulation. In fact equations 1 and 3 , lead to a mixed-integer nonlinear optimization program. However if one defines the system capacity a priori, the problem can be formulated as an easy to solve mixed-integer linear program(MILP). This decoupling allows one to search the solution space for the capacity that minimizes GHG emissions. This is the basis of a simple global optimization technique called controlled random search (CRS). Sections 4.1 and 4.2 describe the MILP formulation and the CRS algorithm, respectively. Section 4.3 describes how the CHP attributable GHG emission reductions were calculated.

\subsection{Operating Strategy: Mixed-Integer Linear Program}

The operating strategy is decided by a mixed-integer linear program where the objective function is to maximize GHG emissions reductions considering GHG emissions from grid electricity, on-site boiler and combined heat and power system. The full program is described in the following equations

\section{Objective Function}

$$
\max \sum_{t \in T}\left(e_{g} e_{t}+e_{b} h_{t}-e_{n g} f_{t}\right)
$$




\section{Subject to}

$$
\begin{gathered}
0 \leq e_{t} \leq E_{t} \forall t \in T \\
0 \leq h_{t} \leq H_{t} \forall t \in T \\
0 \leq e_{t} \leq p_{t}^{h}+p_{t}^{l} \forall t \in T \\
0 \leq h_{t} \leq q_{t} \forall t \in T \\
\mu_{t} X l \leq p_{t}^{h}+p_{t}^{l} \leq \mu_{t} X \forall t \in T \\
\omega_{t} f X \leq p_{t}^{l} \leq f X \\
0 \leq p_{t}^{h} \leq X(1-f) \omega_{t} \\
\mu_{t}, \omega_{t} \in[0,1] \\
p_{t}^{h}, p_{t}^{l}, h_{t}, e_{t} \geq 0
\end{gathered}
$$

where $e_{g}$ is the GHG emissions coefficient of electricity from the grid $\left(\mathrm{g} \mathrm{CO}_{2} \mathrm{e} / \mathrm{kWh}\right), e_{b}$ is the GHG emissions coefficient for thermal energy produced from an on-site boiler $\left(\mathrm{g} \mathrm{CO}_{2} \mathrm{e} / \mathrm{kWh}\right), E_{t}$ is the electricity demand of the building in hour $t$, and $H_{t}$ is the thermal demand of the building in hour $t$.

The decision variables are the electrical energy produced by the CHP system and used by the building in hour $\mathrm{t}\left(e_{t}\right)$, the thermal energy produced by the CHP system and used by the building in hour $t\left(h_{t}\right)$, and the electrical power output of the CHP system in hour $t\left(p_{t}^{h}, p_{t}^{l}, w_{t}\right)$, and the operating status of the CHP system in hour $t,\left(\mu_{t}\right)$.

The constraints defined by equations 10 and 11 ensure that the energy used by the building is not more than the electric an thermal energy demands in any hour. Equations 12 and 13 ensure that the energy produced by the CHP system and used by the building is less than the output of the CHP system. Equation 14 requires the power produced by the CHP system to be within the minimum and maximum outputs. Equations 15 and 16 define the piecewise linear formulation of the CHP power output. Lastly equations 17 and 18 define the integrality and non-negative constraints on the decision variables. This formulation allows for waste of the electric or thermal energy produced by the CHP system or to not use the system entirely if deemed advantageous.

The CHP capacity and the corresponding electrical efficiency are not decision variables in the MILP formulation. For any set of building demands the MILP described above is repeatedly solved for various values of CHP capacity. The system with the largest reductions in building GHG emissions, as found by a controlled random search as described in section 4.2 , was selected as the system capacity. 


\subsection{Sizing Strategy: Controlled Random Search}

In this section the MILP previously described is considered a function, $\operatorname{MILP}(X)$, that takes a system capacity as an input and outputs the GHG emissions reductions. The CRS algorithm finds the capacity that maximizes the GHG emissions reductions by systematically searching the solution space. Initially a capacity is randomly selected from a uniform distribution over an interval of $\pm \Delta$. The GHG emissions reductions the specified capacity are evaluated and recorded. If the reductions are more than the previous solution then a new capacity is selected from a uniform distribution about the new capacity. If the reductions are less than the previous solution, then the solution is discarded or accepted as a new solution with a probability $\phi$. Accepting a sub-optimal solution allows the algorithm to get out of local minima. This procedure was repeated until the algorithm has not found a better solution for 20 iterations. The full controlled random search is defined by Algorithm 1.

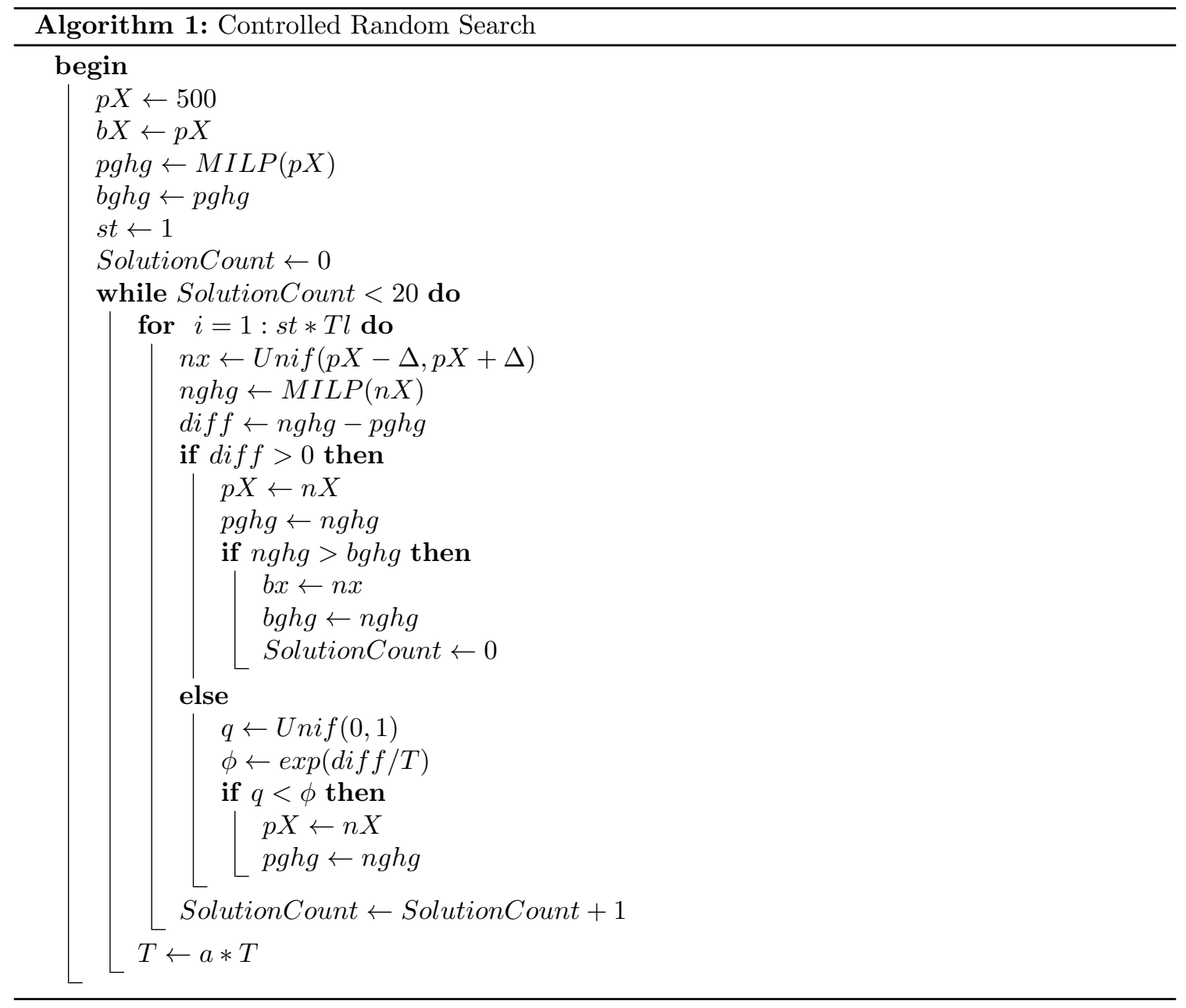




\subsection{Defining CHP Attributable GHG emissions reductions}

One of the intentions of this work is to clarify the additional benefits of CHP systems by disaggregating the GHG emissions reductions that can be achieved by electricity only systems. To that aim, once the CRS has found the capacity that minimizes GHG emissions, a second MILP program is run to calculate the GHG emissions reductions without using any of the waste heat. For that MILP the objective function is changed to

$$
\max \sum_{t \in T}\left(e_{g} e_{t}-e_{n g} f_{t}\right)
$$

and equations 11 and 13 are removed.

The "CHP Attributable" GHG emissions reductions are defined as the difference between the value of the objective function as defined by equation 9 and 19 .

\section{Results and Discussion}

The maximum GHG emissions reductions for the simulated buildings and CHP system types was estimated for different values of GHG emission rates from grid electricity. The following sections describe the effect on the hourly operation of the CHP system, building size for thermal systems, CHP system type, and climate for differing values of GHG emissions rates from grid electricity. The CHP attributable reductions are calculated and discussed as well. The section finishes by evaluating the GHG emissions reductions for each simulated city considering the average GHG emissions reductions from local electricity production.

\subsection{Optimal CHP Systems under "High" and "Low" GHG emissions scenarios}

There are several changes in the optimal sizing, operation, and GHG emission reductions under the "High" and "Low" grid electricity GHG emissions rates. To introduce the changes, the findings for a large residential building in Baltimore, MD will first reviewed.

Figure $3(\mathrm{~A})$ and (B) depict the thermal energy demand, electric energy demand, consumed CHP thermal output and consumed CHP electric output over 24 hours for January 15, April 15th, and August 15th under "High" and "Low" GHG emissions rates, respectively. When the GHG emissions rate from grid electricity is "High", the CHP system is operational for every hour of the year. The output of the CHP system tracks the electricity demand and the waste heat is used whenever there is a concurrent thermal demand. This leads to GHG emissions reductions for all hours of the year. In contrast when the GHG emissions rate from grid electricity is "Low", the CHP system must simultaneously offset electric and thermal demands in sufficient magnitude to obtain GHG emissions reductions. On January 15th, where the thermal demand is significantly higher than the electricity demand, the CHP system tracks the electricity demand as all the thermal energy can be used. However for a few hours on April 15th, the electric and thermal demand is relatively low compared to the CHP system capacity. Operating the system at part-load to meet those demands would led to higher GHG emissions than the original sources of energy, therefore the system is not used. On August 15 for the entire day, there is not enough thermal demand to justify the CHP operation.

The optimal CHP system size changes as a function of GHG emissions rates as well. One CHP system is meant to provide energy over 8,760 hours of concurrent thermal and electric demands. If the system is over sized there will be significant waste for most of the hours from operating at 
Figure 3: Hourly Dispatch of Internal Combustion Engine Driven CHP System for a Large Residential in Baltimore, MD (Cold Climate) for days in January, April and August. (A) Operation with Electric Grid GHG emissions rate of $750 \mathrm{~g} \mathrm{CO}_{2} \mathrm{e} / \mathrm{kWh}$, Optimal System Capacity: $623 \mathrm{~kW}$, GHG Emissions reductions: 38\% (B) Operation with Electric Grid GHG emissions rate of $300 \mathrm{~g} \mathrm{CO}_{2} \mathrm{e} / \mathrm{kWh}$, Optimal System Capacity: $527 \mathrm{~kW}$, GHG Emissions reductions: $6 \%$

(A)

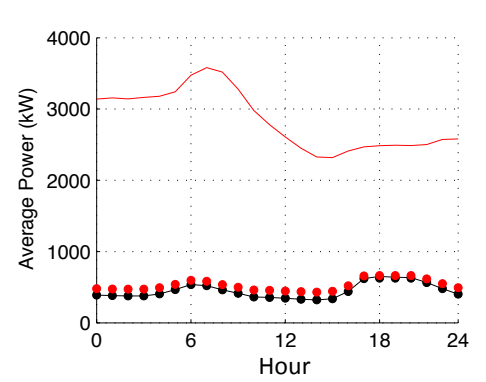

Apr. 15th

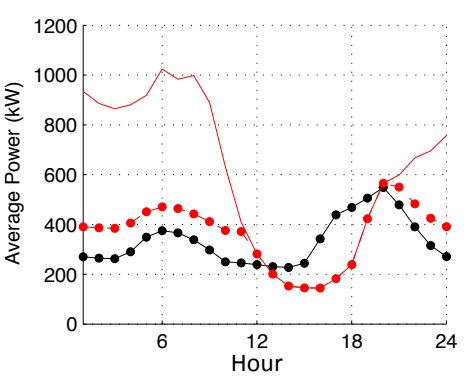

Aug. 15th

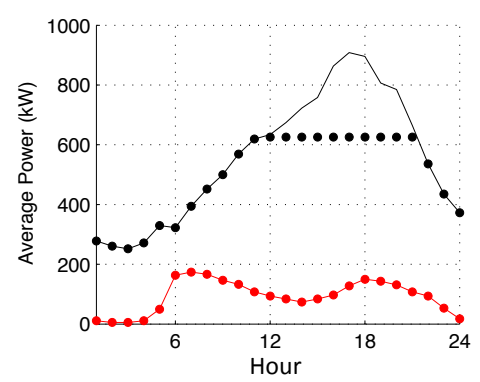

(B)
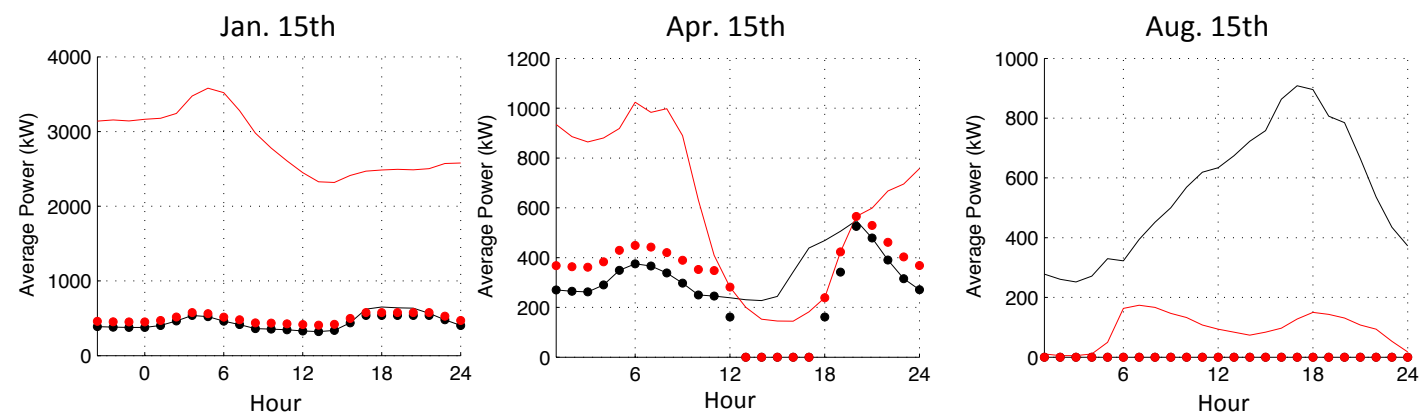

Thermal Demand Utilized CHP Thermal Output — Electric Demand

- Utilized CHP Electric Output 
Figure 4: GHG emissions reductions for the "Large" residential prototypical building in Baltimore, MD from CHP and Electric Only Operation

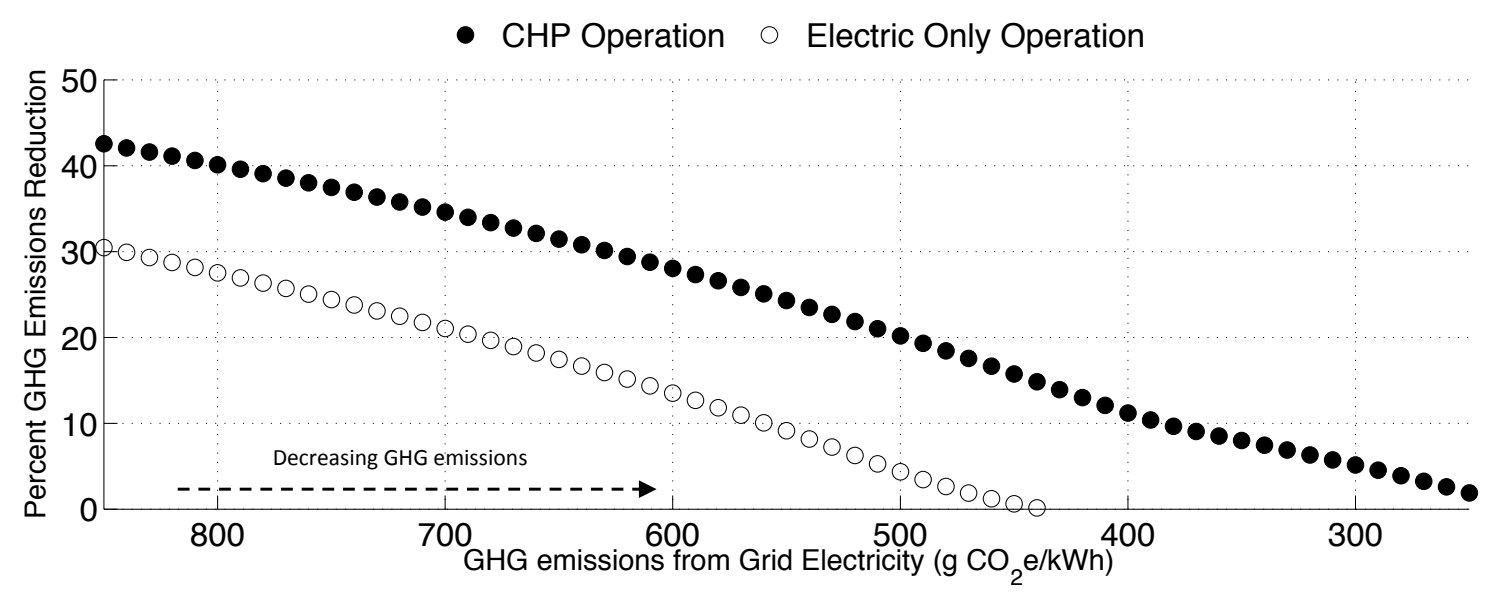

part-load. If the system is undersized, there are missed reductions during times of higher demand. The optimal system balances these options to achieve the largest reductions. Therefore by changing the GHG emissions from grid electricity, both the size and the operating strategy shifts. For this example there is approximately a $100 \mathrm{~kW}$ difference in system capacity between the "High" and "Low" GHG emission scenarios.

Figure 4 depicts the GHG emissions reductions for a "Large" residential building in Baltimore, MD from CHP operation (where waste heat is used) and electric only operation over a range of GHG emission rates from grid electricity. Under the "High" and "Low" GHG emission rates, the GHG emissions reduction reduces from $38 \%$ to $6 \%$. However, under the "High" GHG emissions scenario the majority of the reductions could be achieved by simply generating electricity locally. For the example, this is generally true when GHG emissions from grid electricity are above $600 \mathrm{~g}$ $\mathrm{CO}_{2} \mathrm{e} / \mathrm{kWh}$ as shown in the figure. As GHG emissions decrease it becomes more prudent to use the waste heat to achieve GHG emissions reductions leading the electric only systems to achieve minimal benefit. Overall though the "CHP attributable" reductions, or the difference between the electric only reductions and CHP operation reductions, stay consistent until the GHG emission rate moves toward the break-even point.

\subsubsection{Prime Mover Selection}

Figure 5 depicts the CHP prime mover for each building type, location, and size that led to the largest GHG emissions reductions. Under most scenarios, the PA fuel cells resulted in the largest GHG emissions reductions. These systems have the highest total CHP efficiency and can achieve electrical efficiencies of $40 \%$. As the electrical efficiency for these systems is not a function of size, PA fuel cells are best for both the large and small building sizes although there are a few exceptions.

For "Large" office buildings under the "High" GHG emissions scenario in all but the coldest climates, internal combustion engines provided the largest reductions. This is due to the higher electrical efficiencies that can be achieved by these systems and that energy demands for offices in these climates are dominated by electricity consumption. Similarly large hospital buildings, in 
Figure 5: CHP Prime Mover with Largest GHG emissions reductions for each building type, location, and size under "High" and "Low" grid electricity GHG emission rates. Green: PAFC, Orange: Internal Combustion Engine, Purple: Microturbine

\begin{tabular}{|c|c|c|c|c|c|c|c|c|c|c|c|c|}
\hline & \multicolumn{3}{|c|}{$\begin{array}{l}\text { Large Building } \\
\text { High GHG Emissions }\end{array}$} & \multicolumn{3}{|c|}{$\begin{array}{l}\text { Large Building } \\
\text { Low GHG Emissions }\end{array}$} & \multicolumn{3}{|c|}{$\begin{array}{l}\text { Small Building } \\
\text { High GHG Emissions }\end{array}$} & \multicolumn{3}{|c|}{$\begin{array}{c}\text { Small Building } \\
\text { Low GHG Emissions }\end{array}$} \\
\hline & Off & Res & Hos & Off & Res & Hos & Off & Res & Hos & Off & Res & Hos \\
\hline Miami, FL & & & & & & & & & & & & \\
\hline Houston, TX & & & & & & & & & & & & \\
\hline Phoenix, AZ & & & & & & & & & & & & \\
\hline Atlanta, GA & & & & & & & & & & & & \\
\hline Los Angeles, CA & & & & & & & & & & & & \\
\hline Las Vegas, NV & & & & & & & & & & & & \\
\hline San Francisco, CA & & & & & & & & & & & & \\
\hline Baltimore, MD & & & & & & & & & & & & \\
\hline Albuquerque, NM & & & & & & & & & & & & \\
\hline Seattle, WA & & & & & & & & & & & & \\
\hline Chicago, IL & & & & & & & & & & & & \\
\hline Boulder, CO & & & & & & & & & & & & \\
\hline Minneapolis, MN & & & & & & & & & & & & \\
\hline Mt. Helena, MT & & & & & & & & & & & & \\
\hline Duluth, MN & & & & & & & & & & & & \\
\hline Fairbanks, AL & & & & & & & & & & & & \\
\hline
\end{tabular}

warmer climates where electric energy demands are also above $75 \%$ of total demand, achieve the largest reductions with internal combustion engines. Under the "Low" GHG emissions scenarios where leveraging the waste heat is more crucial, microturbines achieve the highest reductions for some residential buildings in cold, very cold and subarctic climates.

\subsubsection{GHG Emissions Reductions}

The GHG emissions reductions for the "Large" building scenarios are shown in Figure 6. As the efficiency of fuel cell systems has not been modeled as a function of size the GHG emissions reduction for the "Large" and "Small" building scenarios are similar and not depicted.

Under the "High" GHG emissions scenario, hospital and office buildings have fairly consistent savings over all climate zones with hospitals achieving the largest GHG emission reductions. The GHG emissions reductions from residential buildings vary over a much larger range as their electricity and thermal demands are much more variable and climate driven.

Under the "Low" GHG emissions scenario, all building types achieve reductions between 0 and 10\%. Also the GHG emission reductions are much less than the relative change in the grid GHG emissions. As mentioned in previously, under the "Low" GHG emission scenario the operating strategy changes, requiring the system to provide simultaneous thermal and electrical demand to see reductions. This in turn reduces the operating hours and CHP system sizes leading to less overall GHG emissions reductions.

\subsubsection{Operating Hours and Operating Strategy}

As the model formulation allows for a CHP system not to be operated in any given time step, it is interesting to observe the annual operating hours of the CHP system. Figure 7 depicts the 
Figure 6: GHG Emissions reductions under "High" and "Low" GHG emission rates from grid electricity. The length of the bars reflects reductions over all cities and climate zone considered.

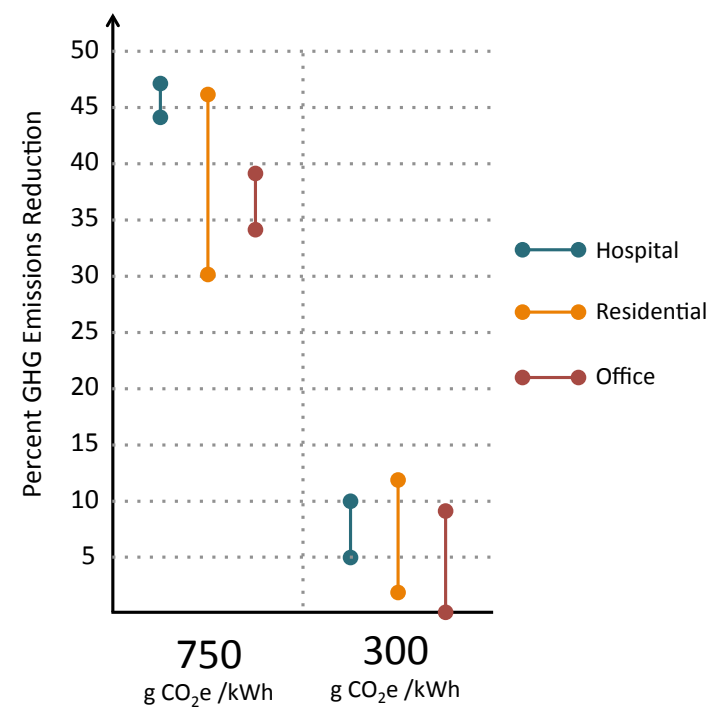

proportion of the year the optimally sized and operated CHP system supplies energy for the "Large" building types under "High" and "Low" GHG emissions rates.

Under the "High" GHG emission rate scenario, hospital and residential building types are operated throughout the year for all climate zones. Office buildings, however, vary in the annual operating hours due to the large variation in electrical demand. It is difficult to meet both the peaks and troughs in demand efficiently with a single system. This indicates that office buildings may be good candidates for multiple prime mover systems.

When the GHG emissions from grid electricity are low there must be a concurrent thermal demand in sufficient magnitude to achieve GHG emissions reductions or else the system is not operated. For this reason under the "Low" GHG emission rate scenarios, the annual operating hours are reduced for the office and residential building types. Hospital buildings, however, have consistent thermal and electrical demands throughout the year in all climates leading to consistently high operating hours.

Additional insights can be made by viewing how the CHP system is dispatched to meet demand. Throughout the literature various heuristics have been used define the CHP operating strategy. The most popular are electric load following and thermal load following [40, 41, 27, 29]. The electric load following heuristic requires the CHP system to meet the electrical demand in all time steps and use waste heat if there is a concurrent thermal demand. The thermal load following heuristic designates the CHP system to meet the thermal demand in all time steps and supply electricity only if there is a concurrent demand. The optimal operating strategy could be one of those heuristics or a mixture of both.

Figure 8 depicts the proportion of the annual operating hours that the CHP systems are dispatched to meet the electrical demand,to meet the thermal demand, at minimum part-load, or at maximum capacity. Viewing these values allows one to discern how closely the heuristics approximate the ideal operation. 
Figure 7: Annual Operation Hours (Proportion of the Year) for "Large" Office, Residential, and Hospital Buildings under "High" and "Low" GHG emissions rates from grid electricity

"High" GHG emissions rate "Low" GHG emissions rate

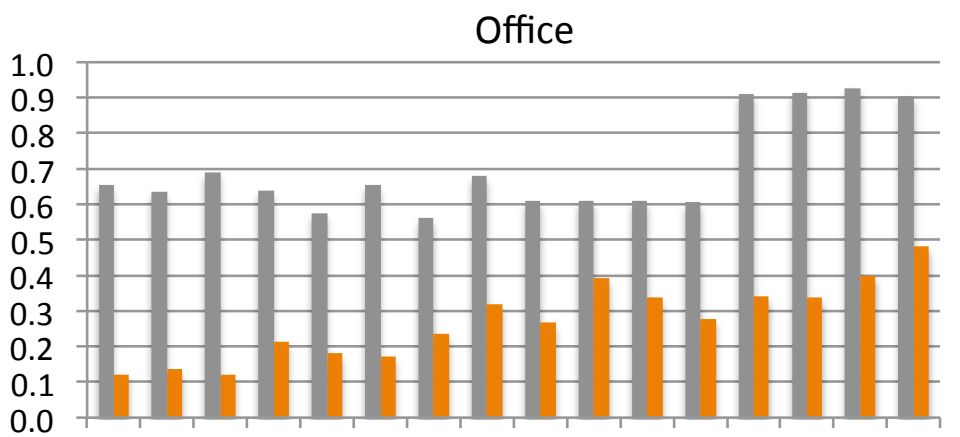

Residential

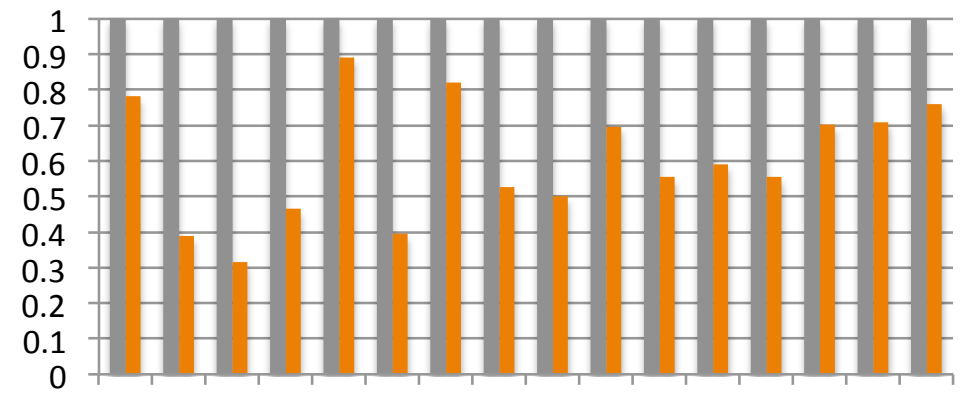

Hospital

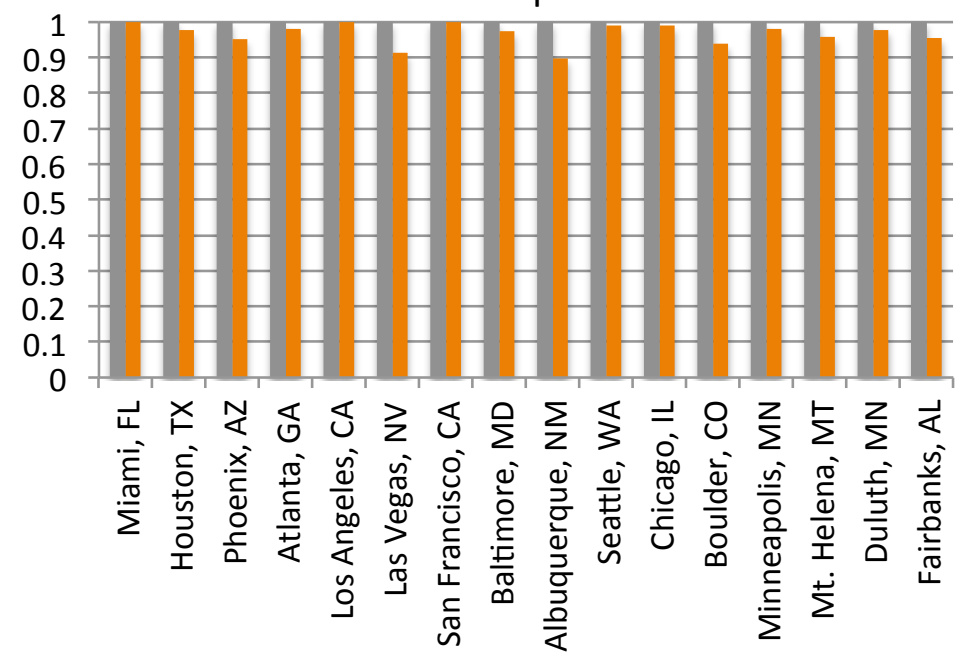


Figure 8: Proportion of Operating Hours where CHP system is dispatched to meet the thermal demand, electrical demand, minimum CHP load, maximum CHP capacity. (a) Building Type: Office ; Grid Electricity Emissions:

"High" (b) Building Type: Residential ; Grid Electricity Emissions: "High" (c) Building Type: Hospital ; Grid Electricity Emissions: "High" (d) Building Type: Office ; Grid Electricity Emissions: "Low" (e) Building Type: Residential ; Grid Electricity Emissions: "Low" (f) Building Type: Hospital ; Grid Electricity Emissions: "Low"
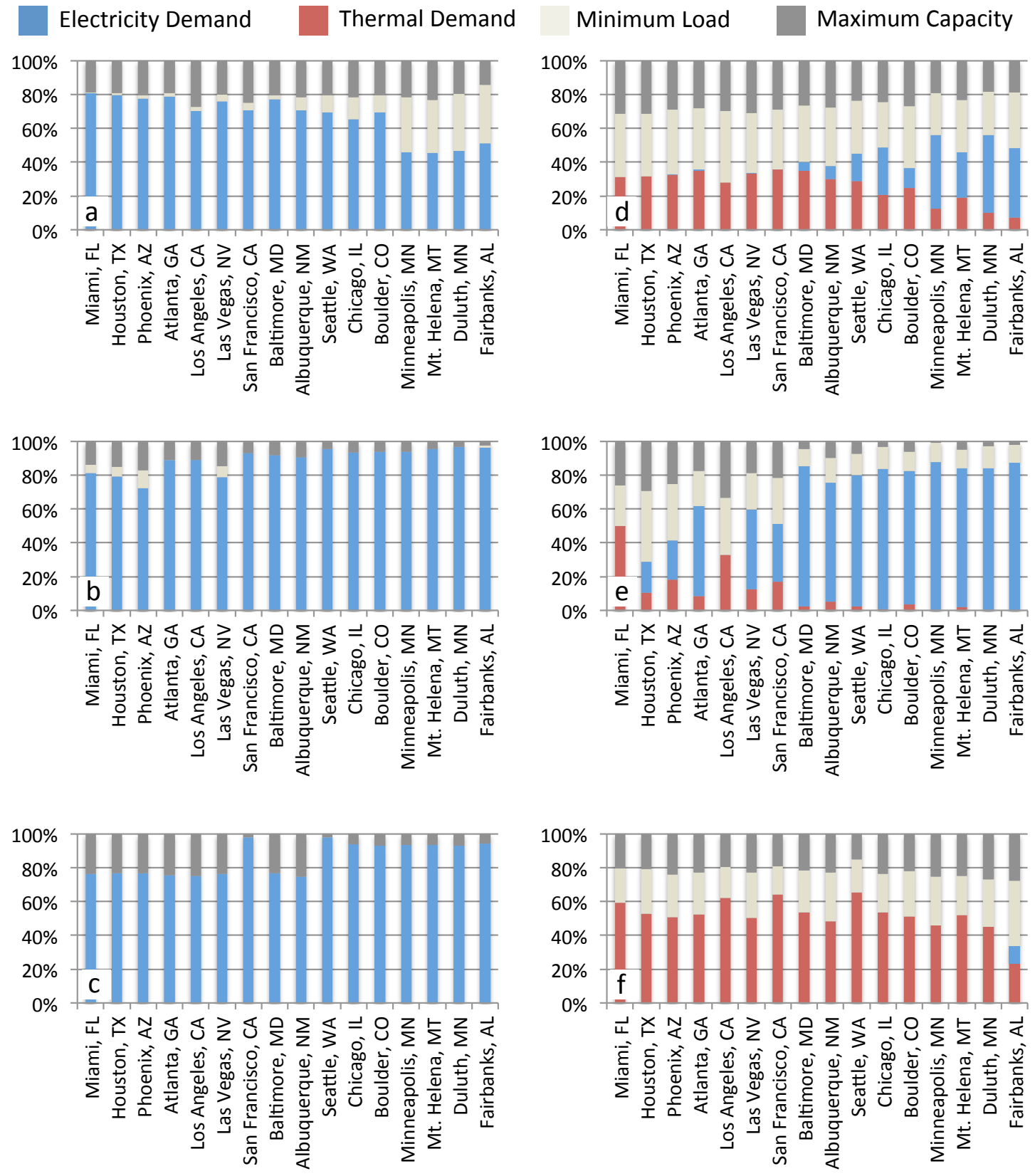
Under the "High" GHG emissions rate scenario as depicted by Figures 8 (a), (b), and (c), the CHP systems are dispatched to mainly meet the electricity demand. With the large GHG emissions coefficient, the largest reductions are achieved by meeting the electrical demand whenever possible.

Under the "Low" GHG emissions rate scenario as depicted by Figures 8 (d), (e), and (f), the results are mixed. For Hospital buildings, the CHP systems are dispatched to mostly meet the thermal demand. CHP systems for the residential buildings in cold climates are dispatched to meet the electrical demand whereas in the warmer climates are dispatched to meet thermal demands. Lastly for Office buildings in warm climates, the CHP systems are dispatched to meet the thermal demand whereas in cold climates are dispatched to meet electrical demands. These trends occur because of the need to have a concurrent thermal and electrical demand to achieve GHG emissions reductions. Therefore the CHP systems are dispatched to meet the lower of the thermal and electrical demands if within the operating parameters of the CHP system.

\subsubsection{Optimal CHP Capacity}

As with the operating hours and operating strategy, the optimal system capacity changes with the GHG emissions scenario as well. Figure 9 depicts the system capacities for the "Large" building types. Under the "High" GHG emissions scenario the systems are sized to be able to meet the larger electrical demands as this leads to the largest reductions. Under the "Low" GHG emissions scenario for the majority of building types and climates, the systems are sized smaller to obtain higher efficiencies during the times of concurrent thermal and electrical demand. The exception are the residential buildings in cold climates where the sizes do not change much between the two scenarios.

\subsubsection{CHP "Attributable" GHG emissions reductions}

The electric only and CHP attributable GHG emissions reductions for the large building types under the "High" GHG emissions scenario is shown in Figure 10. While the reductions considering the contributions that can be achieved with an electric only system range between 35 and $50 \%$ for Office and Hospitals buildings, the CHP attributable reductions are less than $10 \%$ in all but the very cold and subarctic climates. Residential buildings, however, with larger thermal demands have higher CHP attributable reductions, up to $20 \%$. These values illustrate that the reduction from electric only operation can be quite large.

Under the "Low" scenario no reductions can be achieved by an electric only system meaning all of the reductions are CHP attributable. Also as the PA fuel cell is the system of choice, the results are similar for the "Small" building size.

\subsection{Optimal CHP Systems at current GHG Emission Rates}

While the previous analyses focused on the changes in operation for specific GHG emissions scenarios, in reality each city receives electricity from a grid with it's own average GHG emission rate. To understand the implications for CHP systems under the current conditions, the optimal CHP systems were found for the location specific GHG emission rates for the "Large" building types.

The prime movers for each location that yields the largest GHG emissions reduction is shown in Figure 11. Internal combustion engines are selected for the office and hospital building types in warm climates with higher GHG emissions rates to leverage the higher electrical efficiencies. Microturbines are selected for all building types in Seatle, WA due to the very low GHG emissions 
Figure 9: Optimal CHP System Capacity for the "Large" building types under "High" and "Low" GHG emissions rates from grid electricity

“High" GHG emissions rate _L _Low" GHG emissions rate
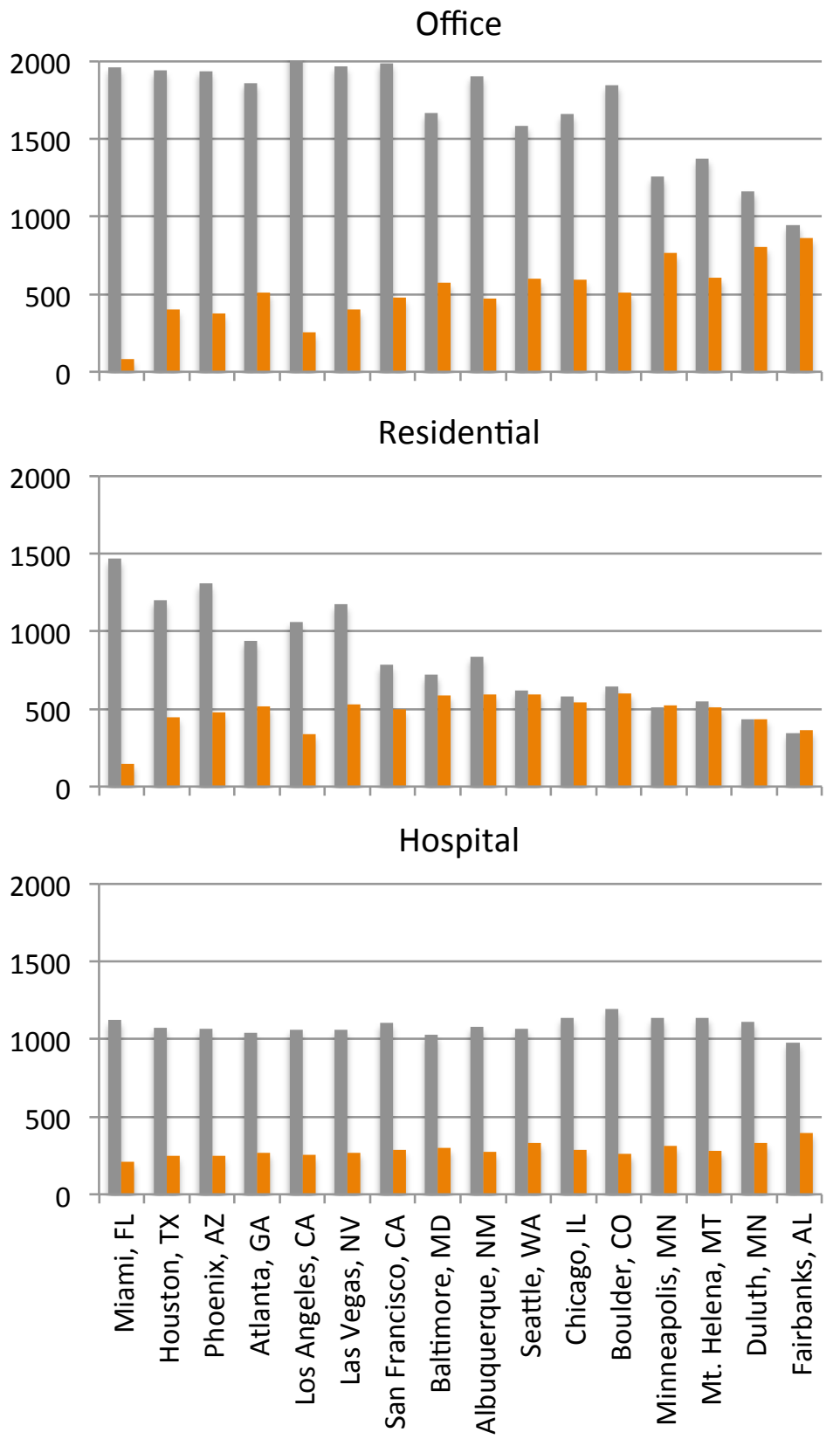
Figure 10: CHP Attributable and Electric Only Operation GHG emissions reductions for "Large" Office, Residential, Hospital prototypical buildings under the "High" GHG emissions scenario
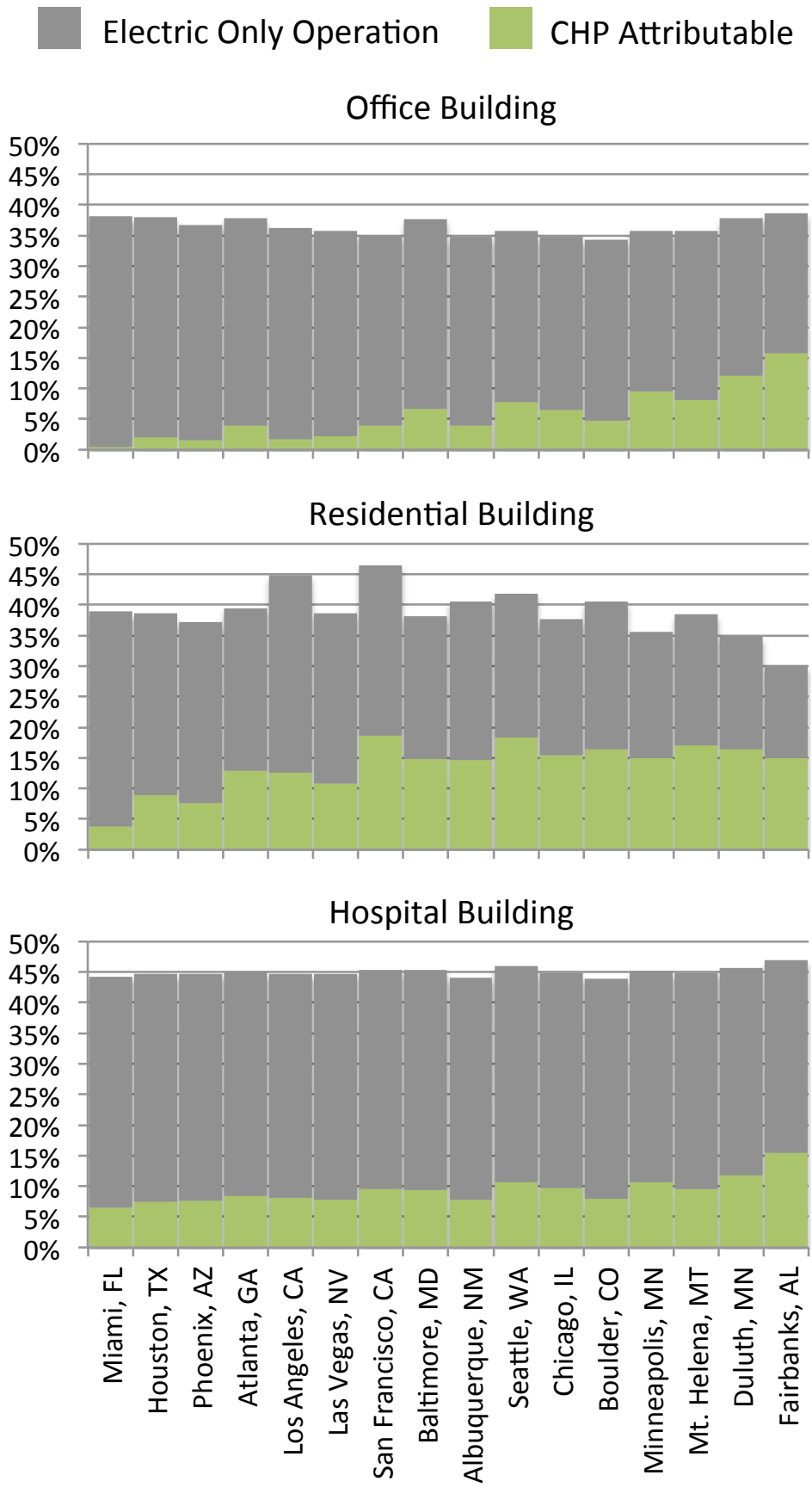
Figure 11: CHP Prime Mover with Largest GHG emissions reductions for "Large" buildings under "2012 GHG emissions rates from grid electricity . Green: PAFC, Orange: Internal Combustion Engine, Purple: Microturbine

\begin{tabular}{|c|c|c|c|c|}
\hline Location & $\begin{array}{c}\text { eGRID rate } \\
\left(\mathrm{g} \mathrm{CO}_{2} \mathrm{e} / \mathrm{kWh}\right)\end{array}$ & Office & Residential & Hospital \\
\hline Miami, FL & 535 & & & \\
\hline Houston, TX & 527 & & & \\
\hline Phoenix, AZ & 542 & & & \\
\hline Atlanta, GA & 604 & & & \\
\hline Los Angeles, CA & 300 & & & \\
\hline Las Vegas, NV & 542 & & & \\
\hline San Francisco, CA & 300 & & & \\
\hline Baltimore, MD & 432 & & & \\
\hline Albuquerque, NM & 542 & & & \\
\hline Seattle, WA & 169 & & & \\
\hline Chicago, IL & 693 & & & \\
\hline Boulder, CO & 831 & & & \\
\hline Minneapolis, MN & 725 & & & \\
\hline Mt. Helena, MT & 725 & & & \\
\hline Duluth, MN & 725 & & & \\
\hline Fairbanks, AL & 582 & & & \\
\hline
\end{tabular}

rate in that region. PA fuel cells were found to achieve the largest reductions for the remaining building types.

The GHG emissions reductions allocated into electric only and CHP Attributable contributions for each building type and location are shown in Figure 12. With the eGRID rates, most building types in cold, very cold, and subarctic climates achieve reductions above $30 \%$ as these locations also have fairly high GHG emissions rates. The CHP Attributable reductions, however, range between 5 and $20 \%$. The residential buildings in these locations consistently show above $15 \%$ CHP attributable reductions. With GHG emissions rates close to the break-even point, all buildings in located in Seattle, WA achieve very little GHG emissions reductions, less than $2 \%$.

Lastly for the majority of building types, an electric load following heuristic best approximates the optimal operating strategy as shown in Figure 13. The exceptions are for Los Angeles and San Francisco, CA where low GHG emissions rates and low thermal demands result in a thermal load following heuristic.

\section{Conclusions}

The goals of the current work were to ascertain the effects of building type, building size, climate and current GHG emissions from grid electricity on the GHG emission reductions possible from natural gas fueled building scale CHP systems. The reductions were estimated for prototypical hospitals, office, and residential buildings simulated in 16 different cities for microturbine, internal combustion engines, and phosphoric acid fuel cells. The results were also explored to understand the changes in system sizing and operation.

The analysis found that the fuel cell systems provided the largest GHG emissions reduction for the majority of building types in all climates under both "High" and "Low" GHG emissions rates from grid electricity. The exceptions where for "Large" Office and Hospital buildings in warm 
Figure 12: CHP Attributable and Electric Only Operation GHG emissions reductions for "Large" buildings under eGRID GHG emissions rates from grid electricity
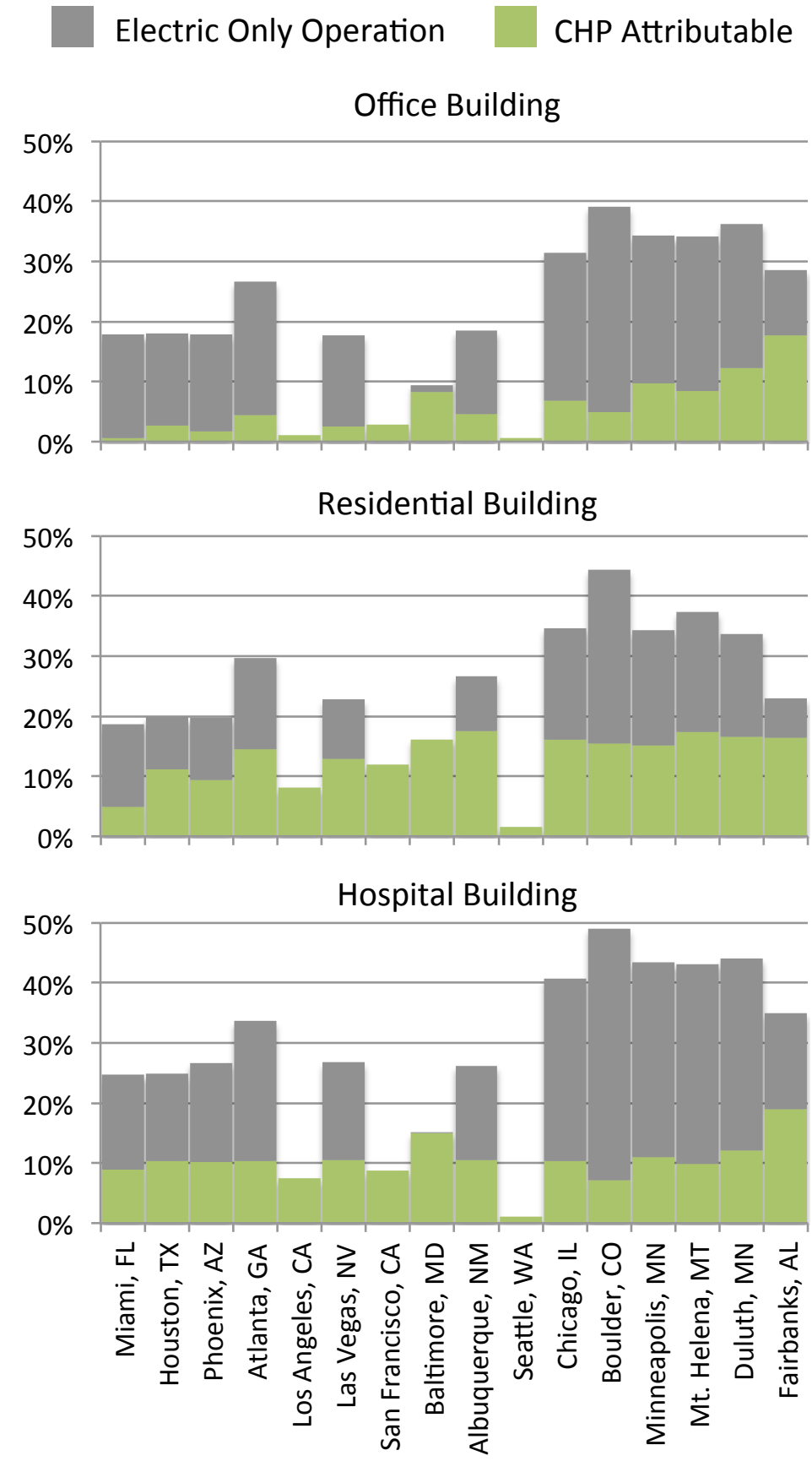
Figure 13: Proportion of Operating Hours where CHP system is dispatched to meet the thermal demand, electrical demand, minimum CHP load, maximum CHP capacity for "Large" buildings under eGRID GHG emissions rates from grid electricity

Electricity Demand

Thermal Demand
Minimum Capacity

Maximum Capacity

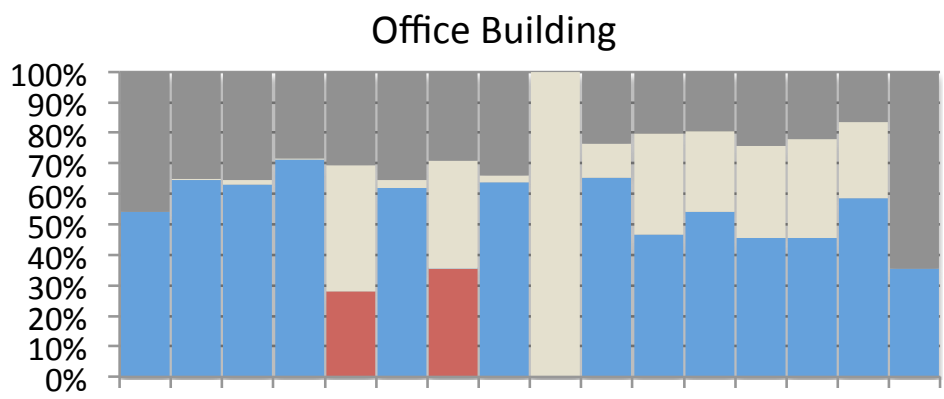

\section{Residential Building}

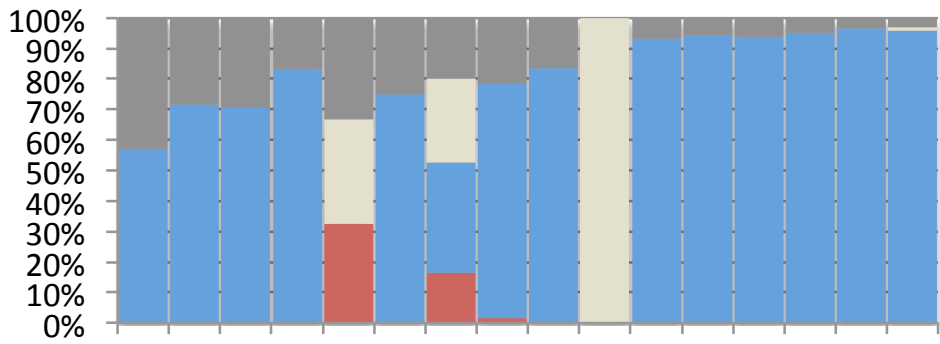

Hospital Building

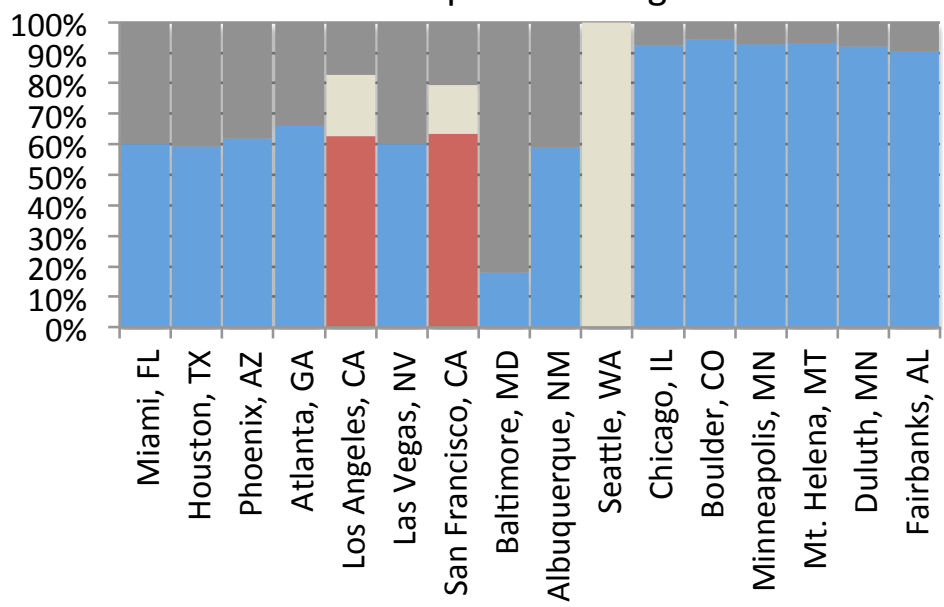


climates where the highest reductions were achieved with internal combustion engines with higher electrical efficiencies. Microturbines were the system of choice for "Large" and "Small" residential buildings in some cold, very cold and subarctic climates.

GHG emissions reductions for these prototypical buildings were between $30 \%$ and $47 \%$ under the "High" GHG emissions scenarios with residential buildings exhibiting the most variability with cities and the corresponding climates. Under the "Low" GHG emissions scenario, GHG emissions reductions for the majority of building types were less than 10\%. Under "High" GHG emission scenarios the majority of GHG emissions reduction come from generating electricity more efficiently with a less carbon intensive fuel. This results in CHP Attributable reductions ranging between 1 and $20 \%$, with residential buildings representing the higher end of the range.

In viewing the resulting CHP operation, the analysis found that the annual operating hours for Office and Residential buildings reduce under "Low" GHG emissions scenarios, as to achieved GHG emissions reduction there must be a concurrent thermal and electrical demand. Hospitals have concurrent thermal and electrical demands throughout the year therefore the operating hours do not diminish under lower GHG emissions scenarios.

In terms of operating strategy, under "High" GHG emissions scenarios, the optimal operating strategy is analogous to an electrical load following strategy, if operating. This is occurs due to the GHG emissions from grid electricity being higher than those produced from the CHP system. Under "Low" GHG emissions scenarios, the operating strategies vary, overall attempting to meet the lower of thermal and electric demands in any hour, if operating. This results in a thermal load following strategy for hospitals and office buildings in warm climates. For residential buildings in cold climates this leads to an electric load following strategy.

Considering current GHG emission rates for each location, the same trends were observed. A mixture of prime movers provided the largest GHG emissions reductions. Internal combustion engines were favored in locations with both high GHG emissions and electrical demands. Microturbines were the prime mover of choice for Seattle, WA where the GHG emissions coefficient is relatively low. Buildings in cold climates with high GHG emission rates where able to achieve GHG emissions reductions between 30 and $50 \%$, however, the CHP attributable reductions where between 5 and $20 \%$. The optimal operating strategy could be approximated with an electric load following heuristic for all locations and building types except for in locations with the lowest GHG emissions rates where a thermal load following approach is favored.

\section{References}

[1] Wen-Shan Tan, Mohammad Yusri Hassan, Md Shah Majid, and Hasimah Abdul Rahman. Optimal distributed renewable generation planning: A review of different approaches. Renewable and Sustainable Energy Reviews, 18:626 - 645, 2013.

[2] G. Pepermans, J. Driesen, D. Haeseldonckx, R. Belmans, and W. D'haeseleer. Distributed generation: definition, benefits and issues. Energy Policy, 33(6):787 - 798, 2005.

[3] P. Chiradeja and R. Ramakumar. An approach to quantify the technical benefits of distributed generation. IEEE Transactions on Energy Conversion, 19(4):764-773, Dec 2004.

[4] Gianfranco Chicco and Pierluigi Mancarella. Distributed multi-generation: A comprehensive view. Renewable and Sustainable Energy Reviews, 13(3):535 - 551, 2009. 
[5] Jian Zhang, Heejin Cho, and Alta Knizley. Evaluation of financial incentives for combined heat and power (chp) systems in u.s. regions. Renewable and Sustainable Energy Reviews, 59:738 762,2016 .

[6] Scott Kelly and Michael Pollitt. An assessment of the present and future opportunities for combined heat and power with district heating (chp-dh) in the united kingdom. Energy Policy, 38(11):6936 - 6945, 2010. Energy Efficiency Policies and Strategies with regular papers.

[7] Paul L Lemar Jr. The potential impact of policies to promote combined heat and power in \{US\} industry. Energy Policy, 29(14):1243 - 1254, 2001. Scenarios for a clean energy future.

[8] James E. Brown, Chris N. Hendry, and Paul Harborne. An emerging market in fuel cells? residential combined heat and power in four countries. Energy Policy, 35(4):2173 - 2186, 2007.

[9] Kevin Brown and Simon Minett. History of chp developments and current trends. Applied Energy, 53(1-2):11 - 22, 1996. Combined Heat and Power in Energy Strategy and Practice.

[10] Mark Hinnells. Combined heat and power in industry and buildings. Energy Policy, 36(12):4522 - 4526, 2008. Foresight Sustainable Energy Management and the Built Environment Project.

[11] U.S. EPA. Catalog of CHP Technologies. U.S. EPA, http://www.epa.gov/chp/technologies.html, 2008.

[12] Kyungtae Yun, Rogelio Luck, Pedro Mago, and Aaron Smith. Analytic solutions for optimal power generation unit operation in combined heating and power systems. J. Energy Resour. Technol., 134, 2011.

[13] A.D. Hawkes and M.A. Leach. Cost-effective operating strategy for residential micro-combined heat and power. Energy, 32(5):711 - 723, 2007.

[14] Firdaus Basrawi, Thamir K. Ibrahim, Khairul Habib, and Takanobu Yamada. Effect of operation strategies on the economic and environmental performance of a micro gas turbine trigeneration system in a tropical region. Energy, 97:262 - 272, 2016.

[15] Pedro J. Mago, Rogelio Luck, and Amanda D. Smith. Environmental evaluation of base-loaded chp systems for different climate conditions in the us. International Journal of Ambient Energy, 32(4):203-214, 2011.

[16] Alta Knizley and Pedro J. Mago. Evaluation of combined heat and power (chp) systems performance with dual power generation units for different building configurations. International Journal of Energy Research, 37(12):1529-1538, 2013.

[17] Pedro J. Mago and Amanda D. Smith. Evaluation of the potential emissions reductions from the use of chp systems in different commercial buildings. Building and Environment, 53(0):74 $-82,2012$.

[18] Gunnel Sundberg and Dag Henning. Investments in combined heat and power plants: influence of fuel price on cost minimised operation. Energy Conversion and Management, 43(5):639 $650,2002$.

[19] Michel De Paepe, Peter D'Herdt, and David Mertens. Micro-chp systems for residential applications. Energy Conversion and Management, 47(18-19):3435 - 3446, 2006. 
[20] Antonio M. Pantaleo, Sergio Camporeale, and Nilay Shah. Natural gas-biomass dual fuelled microturbines: Comparison of operating strategies in the italian residential sector. Applied Thermal Engineering, 71(2):686 - 696, 2014. Special Issue: \{MICROGEN\} III: Promoting the transition to high efficiency distributed energy systems.

[21] Hongbo Ren, Weijun Gao, and Yingjun Ruan. Optimal sizing for residential chp system. Applied Thermal Engineering, 28(5-6):514 - 523, 2008.

[22] M.A. Ehyaei and M.N. Bahadori. Selection of micro turbines to meet electrical and thermal energy needs of residential buildings in iran. Energy and Buildings, 39(12):1227 - 1234, 2007.

[23] O.A. Shaneb, G. Coates, and P.C. Taylor. Sizing of residential chp systems. Energy and Buildings, 43(8):1991 - 2001, 2011.

[24] P. Ghadimi, S. Kara, and B. Kornfeld. The optimal selection of on-site $\{\mathrm{CHP}\}$ systems through integrated sizing and operational strategy. Applied Energy, 126(0):38 - 46, 2014.

[25] Bianca Howard, Alexis Saba, Michael Gerrard, and Vijay Modi. Combined heat and power's potential to meet new york city's sustainability goals. Energy Policy, 65(0):444 - 454, 2014.

[26] Antonio Costa and Alberto Fichera. A mixed-integer linear programming (milp) model for the evaluation of chp system in the context of hospital structures. Applied Thermal Engineering, 71(2):921 - 929, 2014. Special Issue: \{MICROGEN\} III: Promoting the transition to high efficiency distributed energy systems.

[27] Woojin Cho and Kwan-Soo Lee. A simple sizing method for combined heat and power units. Energy, 65(0):123 - 133, 2014.

[28] Zhang Beihong and Long Weiding. An optimal sizing method for cogeneration plants. Energy and Buildings, 38(3):189 - 195, 2006.

[29] A.K. Hueffed and P.J. Mago. Influence of prime mover size and operational strategy on the performance of combined cooling, heating, and power systems under different cost structures. Proceedings of the Institution of Mechanical Engineers, Part A: Journal of Power and Energy, $224,2010$.

[30] Jiang-Jiang Wang, You-Yin Jing, Chun-Fa Zhang, and Zhiqiang (John) Zhai. Performance comparison of combined cooling heating and power system in different operation modes. $A p$ plied Energy, 88(12):4621 - 4631, 2011.

[31] Pacific Northwest National Laboratory and Oak Ridge National Laboratory. Guide to determining climate regions by county. Technical report, August 2010.

[32] U.S. Department of Energy (US DOE). Commerical Buildings Initative: Commerical Reference Building. U.S. Department of Energy (US DOE), http://www1.eere.energy.gov/buildings/ commercialinitiative/ reference buildings.html, 2011.

[33] Energy Information Administration. Commercial building energy consumption survey. US Department of Energy, 2012.

[34] Ge jenbacher type 2 technical specifications. http://site.ge-energy.com/prod_serv/ products/recip_engines/en/downloads/ETS_E_T2_10_screen_August2010.pdf. 
[35] Ge jenbacher type 4 technical specifications. http://site.ge-energy.com/prod_serv/ products/recip_engines/en/type4.htm.

[36] Ge jenbacher type 6 technical specifications. https://www.ge-distributedpower.com/ products/power-generation/up-to-5mw/jenbacher-type- 6 .

[37] Catepillar gas generator set technical specifications. http://www.cat.com/en_US/products/ new/power-systems/electric-power-generation.html.

[38] Capstone microturbine technical specifications. http://www.capstoneturbine.com/_docs/ Product\%20Catalog_ENGLISH_LR.pdf.

[39] Pure cell model 400 technical specifications. http://www.doosanfuelcellamerica.com/ energy/purecellmodel400system/.

[40] Hongbo Ren and Weijun Gao. Economic and environmental evaluation of micro $\{$ CHP $\}$ systems with different operating modes for residential buildings in japan. Energy and Buildings, 42(6):853 - 861, 2010.

[41] B. Howard, L. Parshall, J. Thompson, S. Hammer, J. Dickinson, and V. Modi. Spatial distribution of urban building energy consumption by end use. Energy and Buildings, 45(0):141 $151,2012$. 